San Jose State University

SJSU ScholarWorks

Doctoral Projects

Master's Theses and Graduate Research

Spring 5-2016

\title{
A Comparison of Educational Approaches to the End-of-Life- Nursing Education Consortium (ELNEC) Course
}

Jennifer L. Bodine

California State University, Northern California Consortium Doctor of Nursing Practice

Follow this and additional works at: https://scholarworks.sjsu.edu/etd_doctoral

Part of the Critical Care Nursing Commons, Geriatric Nursing Commons, and the Other Nursing Commons

\section{Recommended Citation}

Bodine, Jennifer L., "A Comparison of Educational Approaches to the End-of-Life-Nursing Education Consortium (ELNEC) Course" (2016). Doctoral Projects. 48.

DOI: https://doi.org/10.31979/etd.xccv-ahg5

https://scholarworks.sjsu.edu/etd_doctoral/48

This Doctoral Project is brought to you for free and open access by the Master's Theses and Graduate Research at SJSU ScholarWorks. It has been accepted for inclusion in Doctoral Projects by an authorized administrator of SJSU ScholarWorks. For more information, please contact scholarworks@sjsu.edu. 


\begin{abstract}
A COMPARISON OF EDUCATIONAL APPROACHES TO THE ENDOF-LIFE NURSING EDUCATION CONSORTIUM (ELNEC) COURSE
\end{abstract}

Purpose: The purpose of this project was to compare the effectiveness of two different educational approaches to teaching the End of Life Nursing Education Consortium course.

Background: Terminally ill patients frequently visit the emergency department for palliative care. However, various references show that staff does not have the knowledge base necessary to provide quality end-of-life care in the emergency setting.

Method: Participants from the emergency department at a Level I Trauma Center were recruited. A quantitative, cross-sectional pilot study was conducted to investigate whether lecture or lecture with simulation was more effective in increasing the knowledge base of participants regarding end-of-life care.

Results: The lecture only and lecture with simulation groups were compared and showed no statistical significance between groups. However, when modules were examined individually, statistical significance was achieved in both groups for varying modules.

Conclusion: As terminally ill patients continue to use the emergency department for pain and symptom management and end-of-life care, emergency staff must be provided with educational opportunities and resources regarding end-of-life care. The ELNEC course is one method for increasing the end-of-life knowledge base for nurses.

Jennifer L Bodine

May 2016 
A COMPARISON OF EDUCATIONAL APPROACHES TO THE ENDOF-LIFE-NURSING EDUCATION CONSORTIUM (ELNEC) COURSE

by

Jennifer L. Bodine

A project submitted in partial fulfillment of the requirements for the degree of Doctor of Nursing Practice California State University, Northern Consortium

Doctor of Nursing Practice

May 2016 


\section{APPROVED \\ For the California State University, Northern Consortium \\ Doctor of Nursing Practice:}

We, the undersigned, certify that the project of the following student meets the required standards of scholarship, format, and style of the university and the student's graduate degree program for the awarding of the master's degree.

Jennifer L. Bodine

Project Author

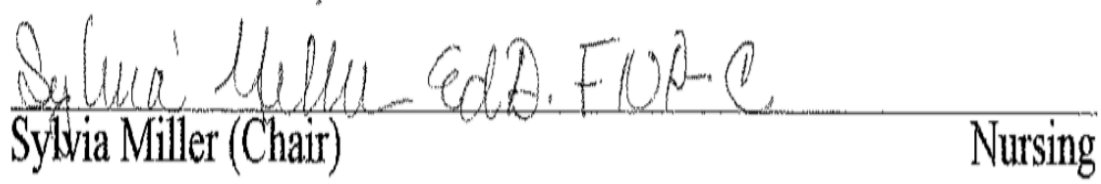
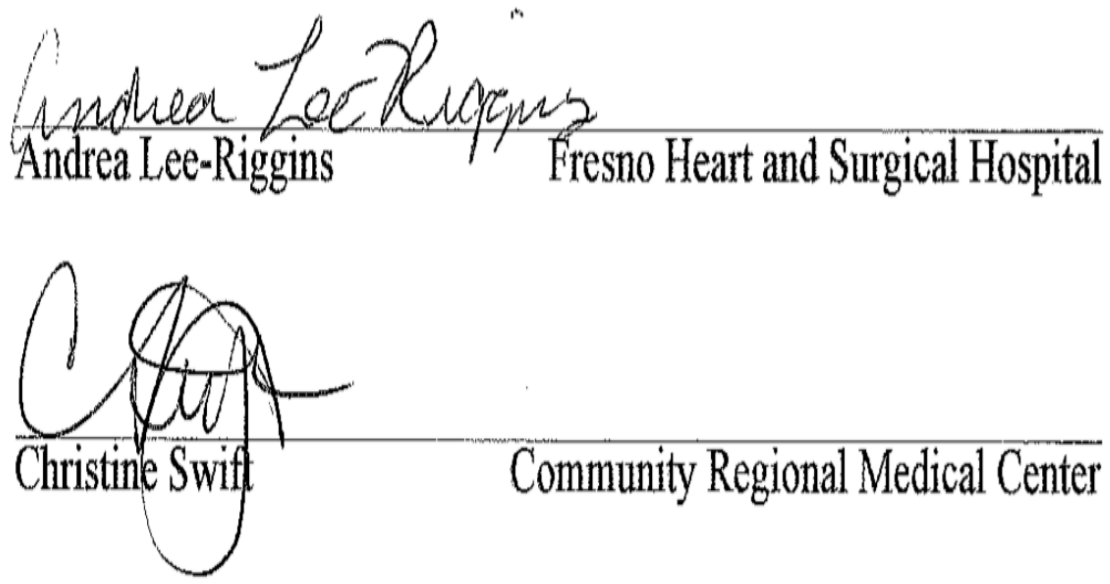


\section{AUTHORIZATION FOR REPRODUCTION}

\section{OF DOCTORAL PROJECT}

$\mathrm{X}$

I grant permission for the reproduction of this project in part or in its entirety without further authorization from me, on the condition that the person or agency requesting reproduction absorbs the cost and provides proper acknowledgment of authorship.

Permission to reproduce this project in part or in its entirety must be obtained from me.

Signature of project author: Lennder of Bodine 


\section{ACKNOWLEDGMENTS}

I would like to thank my husband, Tommy for his endless support and love, and my parents George and Millie Martine for their constant love and encouragement. My sister Melanie for always answering the phone.

I would like to thank my project chair, Sylvia Miller for her invaluable feedback. I would like to thank my committee members Christine Swift and Andrea LeeRiggins. I would not have been able to complete this project without Christine's unwavering belief that this could be done. 


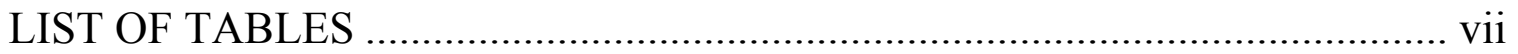

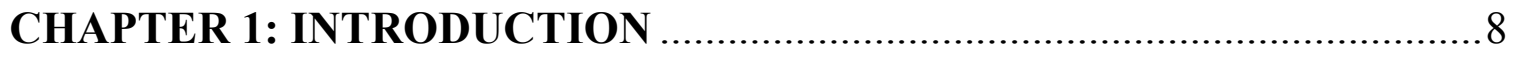

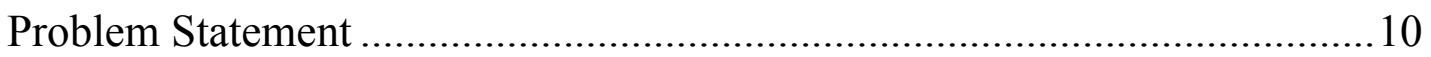

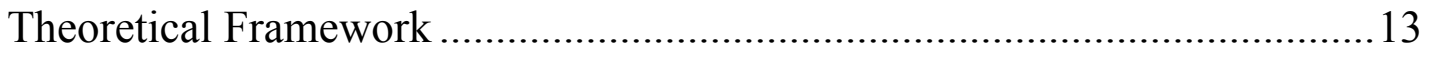

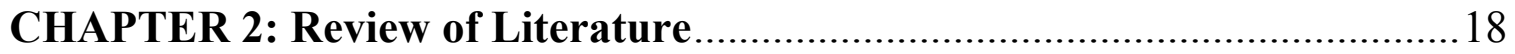

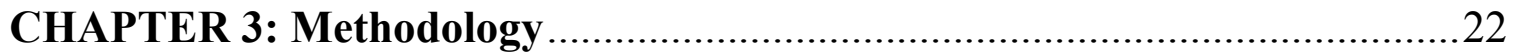

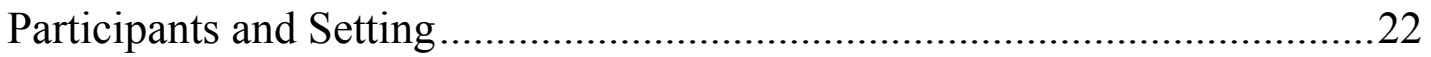

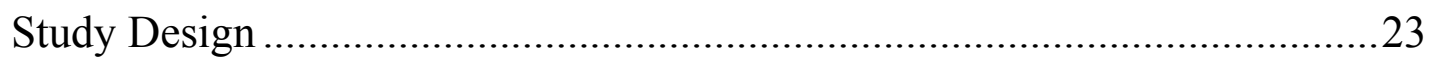

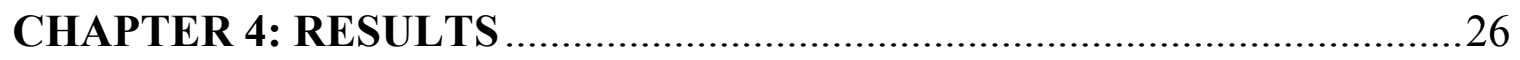

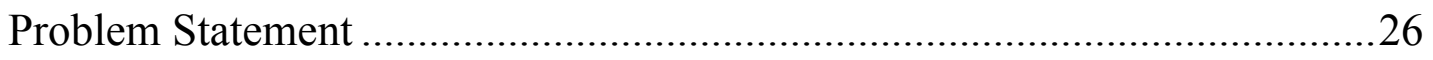

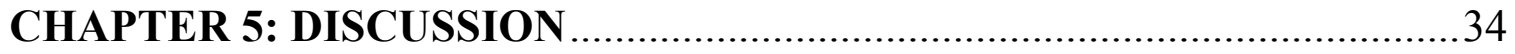

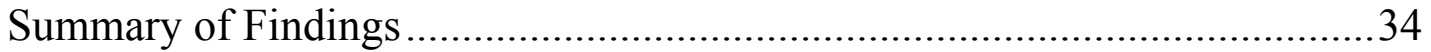

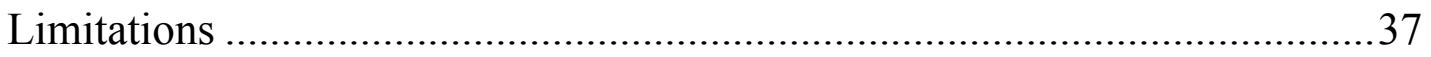

Recommendations for Future Research ......................................................38

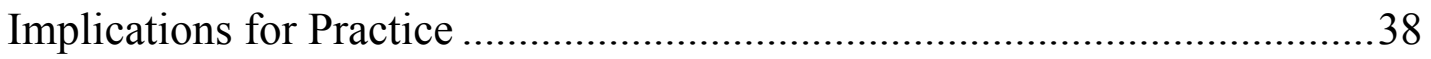

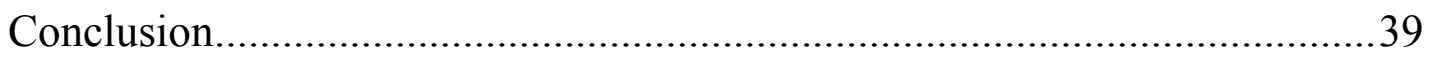

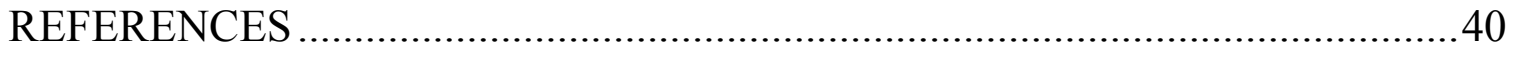

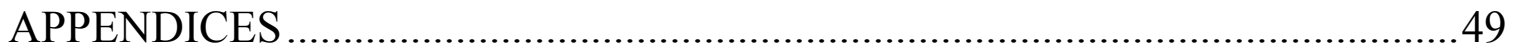

APPENDIX A: EMAIL TO PARTICIPANTS …........................................50

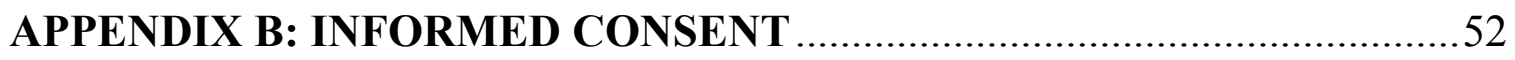

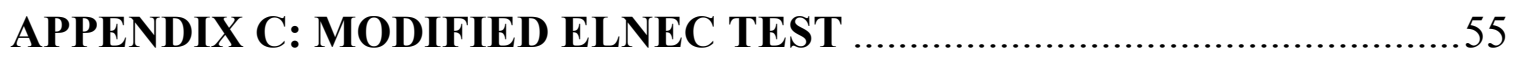

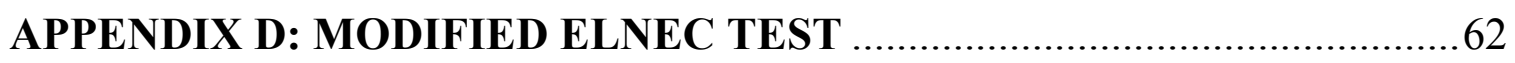




\section{LIST OF TABLES}

Page

Table 1. Study Participant Characteristics...........................................................2

Table 2. Independent Samples t-tests of ELNEC Variables and Group..................30

Table 3. Dependent Samples t-tests of ELNEC Variables and Time for Lecture

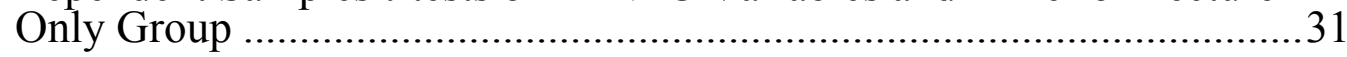

Table 4. Dependent Samples t-tests of ELNEC Variables and Time for Lecture with Simulation Group ............................................................................... 31

Table 5. Dependent Samples t-tests of ELNEC Variables and Time for the Whole Sample 


\section{CHAPTER 1: INTRODUCTION}

Although death is a certainty for everyone, the care of the dying is an evershifting variable that depends on the aging population, access to care, and evolving health care systems (Institute of Medicine [IOM], 2015). Before the twentieth century, death typically occurred at a younger age however with scientific advancements, most deaths now occur in adults at an advanced age (Carr, 2012). In the nineteenth century, deaths occurred in the home; in the twentieth century, it occurred, more often than not, in hospitals with physicians at hand. In the 1970s, the hospice movement, which promotes palliative care, offered terminally ill patients the opportunity to die at home, providing them with pain and symptom management, open communication, and a peaceful death (Carr, 2012).

In the United States (U.S.), the terms hospice and palliative care are often used interchangeably. Hospice programs provide terminally ill patients, with 6 or fewer months to live, with palliative care available from an interdisciplinary team (Meier, 2011). Palliative care provides relief from pain and symptoms that result from a lifelimiting disease (World Health Organization, 2014). End-of-life (EOL) care can encompass both hospice and palliative care because it involves relieving symptoms that are prevalent in actively dying persons (Mayo Clinic, 2014).

In 2012, the National Hospice and Palliative Care Organization (NHPCO) estimated that 1,113,000 people in the U.S. died while under the care of a hospice program. Of those deaths, $6.6 \%$ occurred in acute care hospitals (NHPCO, 2013). A study that examined emergency department use in the last months of life for patients aged 
65 years and older $(N=4,158)$ found that $75 \%$ visited an emergency department in the last 6 months of life and 51\% visited in their last month of life (Smith et al., 2012).

Although the emergency department may not be the ideal place to receive EOL care, many terminally ill patients still use this service because they lack knowledge of symptom management and have been sent by outpatient providers (Smith et al., 2010). Lamba and Quest (2011) observed that people may call emergency services reflexively when they need support devices or medications and cannot reach hospice staff. Also, because hospice programs do not require patients to have a do-not-resuscitate (DNR) order, their staff may tell patients to call 911 in a crisis (Lamba \& Quest, 2011). Finally, late referrals to hospice leave patients and families unprepared for EOL symptoms, and fear may cause them to use an emergency department (Lamda \& Quest, 2011).

Emergency department staff have identified several barriers to delivering EOL care. The emergency department's chaotic environment makes it difficult to make EOL decisions and provide EOL care (Beckstrand, Wood, Callister, Luthy, \& Heaston, 2012). Emergency department staff are charged to triage patients rapidly with a focus on discharge or admission. Often, emergency department staff are not equipped to provide interventions for symptoms associated with EOL (Beckstrand, Wood, et al., 2012).

Because most EOL models focus on chronic illnesses, no guidelines have been disseminated on the acute symptoms of terminal illness (Beckstrand, Wood, et al., 2012). Some hospitals may not have the resources to support a palliative care team in the emergency department, and emergency staff may not have the educational background to provide quality EOL care. 
Several studies (Beckstrand, Giles, Luthy, Callister, \& Heaston, 2012;

Beckstrand, Rasmussen, Luthy, \& Heaston, 2012; Beckstrand, Wood, et al., 2012; Smith et al., 2012; Smith et al., 2010) have discussed barriers to delivering EOL care in emergency settings and have identified potential interventions. Interventions include staff input into departmental design for better EOL experiences, allowing nurses to be more available to dying patients, policies for family presence during CPR, improved staff training, early referrals for palliative care, and improved communication between physicians, patients, and family members. However, the implementation of these recommended interventions have yet to be reported in the literature.

\section{Problem Statement}

Although schools of nursing are providing more EOL education than before, it is still inadequate to provide nurses with the knowledge necessary to provide quality EOL care in clinical settings (Jeffers, 2014). Recent initiatives, such as the End-of-Life Nursing Education Consortium (ELNEC), Education in Palliative and End-of-Life CareEmergency Medicine (EPEC), and the Center to Advance Palliative Care's, "Improving Palliative Care in Emergency Medicine” (IPAL-EM), are addressing palliative care in emergency departments. However, the need is still great to provide EOL education to staff who in turn can improve EOL care in emergency departments (Quest, Asplin, Cairns, Hwang, \& Pines, 2011). The project addressed the following questions:

1. Were there mean differences between baseline mean scores on EOL modules and post-ELNEC training mean scores for participants who attended the lecture with simulation courses versus participants who attended the lecture-only courses? 
2. Were there mean differences between baseline mean scores on EOL modules and post-ELNEC training mean scores, separately by group?

3. Were there mean differences between baseline mean scores on EOL modules and post-ELNEC training mean scores for the whole sample?

\section{Purpose}

The Joint Commission's initiative, "Core Principles for End-of-Life Care," is intended to be used by all those who care for the dying across all health care settings (Norton, Hobson, \& Klum, 2011). The initiative promotes alleviation of pain and physical symptoms and the assessment and management of psychological, social, and spiritual problems throughout a health care organization (Cassel \& Foley, 1999). Thus, the same basic principles of EOL care apply wherever patients are being cared for in a hospital.

The emergency department is an area that is designated for individuals who need immediate care for acute or life-threatening illnesses. Despite best efforts to sustain life, approximately 240,000 people died in U.S. emergency departments in 2010 (Centers for Disease Control and Prevention, 2014). More than one third of deaths in emergency departments are chronically ill patients in the terminal phase of their disease trajectory. Although death is a normal occurrence in emergency settings, emergency staff are often uncomfortable delivering care to dying patients (Norton et al., 2011). Some of the perceived barriers to EOL care are lack of privacy, poor communication, lack of an EOL care model, lack of communication, demanding workloads, and lack of EOL education specific to emergency medicine (Beckstrand, Giles, et al., 2012; Beckstrand, Wood, et al., 2012). 
The Emergency Nurses Association (ENA; 2013) released a position statement that outlines the expectations of emergency nurses when caring for EOL patients. The ENA acknowledges that difficulties can occur in the specialized area of emergency medicine such as time restrictions, minimal data on patients, and public pressure to render high quality care. Despite these challenges, the ENA believes that emergency nurses should receive education specific to EOL care so that they can identify patients who would benefit from palliative or hospice care and become more proficient in providing EOL care to such patients.

Furthermore, emergency nurses are expected to support family involvement in the EOL process and collaborate with palliative care providers. In light of the foregoing issues and the recommendations of the ENA and Joint Commission, this project focused on the education of emergency nurses with an intent to enhance the quality of EOL care in the emergency department. Specific interventions are needed to address the EOL barriers to communication with family members and physicians and pain and symptom management in the emergency department setting.

The purpose of this project was to provide two educational approaches to the ELNEC course to determine if one method was more effective in increasing the knowledge base of emergency nurses about EOL care. The expectation was that nurses would use this knowledge to address the perceived barriers to providing quality palliative care in emergency departments.

The goal was to provide emergency nurses with the EOL competencies required to create an environment that is conducive to providing palliative care. Nurses' selfcompetence in palliative nursing was assessed and those who attended the class are 
considered palliative care "champions" who will role model the behaviors desired in giving EOL care.

\section{Definitions}

The following definitions were used in this project.

- Actively dying. The time associated with a person's impending natural death (Hui et al., 2014).

- Hospice. A program philosophy that uses an interprofessional team to provide pain and symptom management and emotional and spiritual support during the last 6 months of life (Hui et al., 2013).

- Palliative care. The interprofessional administration of care that improves the quality of life for patients and their families throughout the disease trajectory (Hui et al., 2013).

- Terminally ill. An incurable disease which a patient is expected to die from within 6 months or less (Hui et al., 2014).

\section{Theoretical Framework}

\section{Transformative Learning Theory}

Mezirow's (2009) transformative learning theory was used as this project's theoretical framework. The theory assumes that people use personal experiences as a frame of reference to shape their beliefs and actions (Mezirow, 2009). Past experiences bind individuals to preconceptions that shape their perspectives of various situations. Mezirow (2009) refers to these preconceptions as habits of mind that include sociolinguistic, moral-ethical, learning styles, religious, psychological, health, and aesthetic. These habits of mind shape how people understand the world. 
The theory asserts that adults restructure their habits of mind through selfawareness and reflection. Communicative learning and instrumental learning are important components of the transformative learning process. Adults achieve communicative learning through knowledgeable dialogue, which creates defensible beliefs. They achieve instrumental learning when they use evidence-based research to arrive at the truth.

Transformative learning typically occurs after a critical event, a deep assessment of assumptions, or adopting a new role or relationship (Mezirow, 2009). These events trigger adults to question their habits of mind, which leads them to a new understanding of the world. Mezirow (2009) determined that transformative learning requires both critical self-reflection and contributing to a dialogue in a complete and unreserved manner. The reflection caused by a crisis or series of insights causes a person to reevaluate beliefs constructed from past experiences. People can realign their habit of mind in the light of present experiences. This transformation allows individuals to expand their understanding of the world (University of Central Oklahoma, 2012b).

Transformative learning theory was ideal for this project's learning situation. It encourages learners to rethink their assumptions about situations in their environment (Hayes, 2015). In this case, emergency nurses typically see themselves in a life-saving role. They function in a hectic environment driven by the acuity of the patients' conditions. At times, they perceive actively dying patients to be low acuity. But this speaks to the context of their reality. Within that context, there is no time for patients who cannot be saved. 
The learning situation in this project involved teaching emergency nurses four modules of the ELNEC course. The class was based on survey results of perceived barriers to EOL care. In their survey responses, emergency department nurses indicated that poor communication with patients, family members, and physicians was a barrier to EOL care. Additionally, the hospital's palliative care manager volunteered that emergency department nurses needed more education on pain and symptom management for EOL patients.

The educational sessions consisted of four ELNEC modules: an overview of palliative care, communication, symptom management, and pain management. The project's class was presented in two formats: lecture and lecture with simulation. The sessions, which involved a steady dialogue between the instructor and students, encouraged emergency nurses to relate their real-life experiences to the module content.

At the beginning of class, the instructors validated the difficulties emergency nurses have in caring for actively dying persons in a hectic environment. They also acknowledged the nurses' efforts to make the best of their situation. Throughout the course, nurses discussed the barriers to providing quality EOL care. This discussion allowed the nurses to discover the prescriptive, casual, and paradigmatic assumptions that alter their frame of reference.

The nurses discussed how EOL situations should be managed in emergency departments (prescriptive). They suggested interventions to improve these situations (causal). Finally, they expressed their feelings about themselves as people and as emergency nurses (paradigmatic; Glazer \& Stein, 2015). The nurses were encouraged to ask questions and challenge the material if they did not believe it was relevant to their 
environment. These challenges enabled the instructors to present evidence-based research in support of the material to help participants arrive at the truth.

The class was designed to allow the nurses to share their personal experiences in caring for dying patients. In response to a slide on pain management for terminally ill drug addicts, one emergency nurse voiced a rather callous assessment of such patients, "Yes, the patient is obviously in pain while they eat their chips and text on their cell phone." Based on this nurse's unfortunate past experiences, she believes that all drug addicts take advantage of emergency departments to obtain medications. The instructor redirected the nurse by emphasizing that, in this scenario, the drug-addicted patient was also terminally ill and actively dying. The instructor also stressed that, based on research, this type of patient needs more pain medication than average patients due to their high tolerance of drugs. After reflection, the student acknowledged that this patient needed medication for the pain caused by his terminal illness.

The goal of transformative learning is to enable people to be open-minded in situations through self-reflection and unrestricted dialogue (University of Central Oklahoma, 2012a). After the nurses discussed perceived barriers, potential interventions in the emergency setting were reviewed. The instructors continuously emphasized that the information being presented was important not only to patients and families but nurses as well.

At the end of class, participants were asked if they had learned anything that would change their practice as a result of attending the course. This question prompted participants to reassess their beliefs once more before leaving class. The class gave 
participants an opportunity to base future decisions on evidence rather than previously held assumptions.

Transformative learning can help emergency nurses challenge their beliefs, which could dramatically alter the importance they place on actively dying patients. Providing nurses with evidence-based information and interventions that they can use in their practice environment may allow them to create feasible plans of care for their actively dying patients. The dialogue that occurred during the class allowed nurses to vent their frustrations and fears, which, Mezirow (2009) noted, leads to transformative learning. In summary, the need for improved competencies in EOL care in emergency settings is evident. Emergency nurses may care for terminally ill patients at any time during their disease trajectory. Not only must they be prepared to deliver palliative care but also to act as patient advocate and to encourage patients and families to act as independently as situations allow. 


\section{CHAPTER 2: REVIEW OF LITERATURE}

A literature review was conducted to assess the barriers nurses found in delivering EOL care in emergency departments, the effectiveness of the ELNEC for nurses, and the effectiveness of simulations for EOL education. A search of the CINAHL, Google Scholar, and PubMed databases used various combinations of these keywords: EOL care, emergency department, barriers, palliative care, hospice, terminally ill, actively dying, ELNEC, simulation, education, and nursing. References in relevant articles led to further searches.

The literature leaves no doubt of the need for more EOL education. The IOM (2015) has recommended that academic institutions, regulatory bodies, and health care systems recognize the need for a more robust palliative care curriculum for health care professionals. The deficiency in providing adequate and comprehensive EOL education begins in the academic setting. Undergraduate and graduate nursing programs lack appropriate EOL curricula (Gillan, van der Riet, \& Jeong, 2014a; Paice et al., 2006; Schlairet, 2009). However, the American Association of Colleges of Nursing (AACN, 2016) is working to rectify this shortcoming by issuing its new document CARES (Competencies and Recommendations for Educating Undergraduate Nursing Students: Preparing Nurses to Care for the Seriously Ill and Their Families), which identifies 17 palliative care competencies that nursing students should acquire by graduation. This can be possible by making the ELNEC curriculum available to undergraduates online.

Beckstrand, Giles, et al. (2012) noted that, even though practicing nurses may have received EOL education, it may not have been adequate for their needs. Researchers found that continuing education in EOL care for practicing oncology nurses 
decreased by $11 \%$ when compared with their previous study, which as conducted 10 years earlier (White \& Coyne, 2011; White, Coyne, \& Patel, 2001). However, Schlairet (2009) noted that continuing education was effective in improving EOL knowledge, skills, and attitudes. Continuing education for palliative and EOL care is needed in emergency departments (Heaston, Beckstrand, Bond, \& Palmer, 2006; Norton, Hobson, \& Kulm, 2011; Quest, Herr, Lambda, \& Weismann, 2013) because all providers should have a basic understanding of palliative care and emergency departments are the typical entry point for patients requiring this care (Grudzen, Stone, \& Morrison, 2011).

Communication during EOL situations, care of hospice patients, and understanding and improving pain and symptom management have been identified as needed areas of education in emergency departments (Chan, 2006; Eby, 2008; Smith et al., 2010). Recognizing emergency nurses' responsibility for EOL patients, the Center to Advance Palliative Care (Chan et al., 2011), with support from the ENA (2013), issued a position statement that emergency nurses should receive training and education on palliative and EOL care. Educating nurses is an effective way to integrate palliative care into emergency settings (Grudzen et al., 2011; Quest et al., 2013).

The Study to Understand Prognoses and Preferences for Outcomes and Risks of Treatment (SUPPORT) showed that care of EOL patients was inadequate (Sherman, Matzo, Rogers, McLaughlin, \& Virani, 2005). Aggressive interventions were administered until EOL, communication between physicians and EOL patients was subpar, and pain management was insufficient (Sherman et al., 2005). The ELNEC was developed in response to nurses' need for better EOL education. As of 2012, 400,000 nurses and health care providers have received ELNEC training. Of note, more health 
care personnel in California have participated in ELNEC than health care personnel in any other state (AACN, 2012).

The ELNEC offers eight curricula, each specific to an area of health care. Despite having taken the ELNEC course in nursing school, nurses found that they did not fully understand its content until they actually began caring for dying patients (Barrere \& Durkin, 2014). Thus, the curriculum may be of most benefit to nurses who are already in practice. The ELNEC-Critical Care curriculum is intended for nurses in intensive care units and emergency departments (AACN, 2012). The ELNEC course uses the validated ELNEC-Knowledge Assessment Test as an assessment tool (Lange, Shea, Grossman, Wallace, \& Ferrell, 2009). Nurses who attend an ELNEC course are expected to become change agents in their specialty area (Sherman et al., 2005).

The ELNEC course uses various teaching methods: PowerPoint presentations with lectures, case studies, and pertinent movie clips. EOL education is usually delivered didactically, which precludes exploration of the emotional side of EOL care (Gillan et al., 2014a). In their review of 16 articles on EOL simulation, Gillan, van der Reit, and Jeong (2014b) found that, regardless of study components, simulation helped nursing students to perceive an increase in knowledge and confidence about EOL care. Furthermore, they found that postsimulation debriefing was a critical factor in the success of the education.

Nursing students who lack clinical experience in caring for dying patients find simulation helpful in reinforcing didactic materials (Leighton \& Dubas, 2009; Tuxbury, McCauley, \& Lement, 2012). One study that used simulation after an ELNEC lecture found that the observers acknowledged a greater change in knowledge base, although no significant difference was noted in the knowledge base of those who played an active part 
in the simulation (Fluharty et al., 2012). Bussman et al. (2015) found that simulation that involves difficult conversations improves EOL conversations between staff, patients and their family members.

This literature review explored the need of EOL education for all nurses. Such education can only enhance the care nurses render to EOL patients and their family members. The ELNEC course has proved to be a beneficial educational tool both nationally and internationally. Although most EOL simulation has been provided to nursing students, research has shown that simulation helps nurses cope with the emotional aspects of EOL care as well as improve participants' knowledge base. This literature search revealed that nurses feel educationally unprepared to deliver EOL care, ELNEC is a reliable curriculum for EOL education, and simulation is helpful in EOL education. 


\section{CHAPTER 3: METHODOLOGY}

This chapter discusses the methodology for this project, which was designed to compare, contrast, and conclude which of two methods of teaching the ELNEC to emergency department nurses was the most effective. This pilot study used a quantitative, cross-sectional, descriptive design.

\section{Participants and Setting}

A convenience sample of emergency nurses $(N=53)$ at a Level I trauma center was invited to participate in this project. Class and enrollment information were advertised through flyers, emails, and staff meetings (Appendix A). Flyers indicated that the ELNEC course was part of this pilot study.

Nurses received consent forms by email, which explained that consent was implied when one voluntarily enrolled in the project (Appendix XX). Those nurses who volunteered were paid for the education hours by their management, provided a free lunch, and received 8.9 continuing education hours, if they attended the full class.

The participants were not informed on which dates the lecture only or lecture with simulation class would be held. Thus, they assigned themselves randomly to either the control or experimental group depending on the day they chose to attend class. During class, the instructor collected demographic information: sex, years of experience in an emergency department, role in the emergency department, and the zone in which participants worked.

The project took place in the 70-bed emergency department of a Level I trauma center in central California. This hospital administered care to over 110,000 patients per year (University of California, San Francisco, 2015). The emergency department has 3 
major trauma rooms, 10 critical care beds, 11 major medical beds, and 25 minor care beds.

\section{Study Design}

Six months before the pilot was initiated, participants were asked to complete Beckstrand's Survey of Emergency Nurses Perceptions of End-of-Life Care (Heaston, Beckstrand, Bond, \& Palmer, 2006). The survey was used to determine course content based on the identified barriers. The principle finding was that the nurses considered the biggest barrier to EOL care in their setting to be poor communication with physicians, patients, and family members. Pain and symptom management was also an issue. The ELNEC-Critical Care curriculum is intended for nurses in intensive care units and emergency departments (AACN, 2012). Accordingly, the project director selected four appropriate modules from the ELNEC Critical Care course: Palliative Care in Critical Care Nursing, Pain Management, Symptom Management, and Communication.

\section{Materials}

End-of-Life Nursing Education Consortium test. The abbreviated 25-question, quantitative ELNEC examination (Appendix XX) was used for pre/post evaluation and was derived from the validated 106-question ELNEC-Knowledge Assessment Test (Lange et al., 2009; Appendix XX). The original test was comprised of nine modules that are considered significant areas for EOL care (Shea, Grossman, Wallace, \& Lange, 2010). The total alpha coefficient was 0.92 , and corrected item-total correlations ranged from 0.51 to 0.72 (Shea et al., 2010).

Test questions were taken from the seven content areas. The questions on the pretest and posttest were the same, but presented in a different order. Three questions 
focused on Nursing Care at the End of Life; six questions were dedicated to Pain Management; three questions addressed Symptom Management; one question addressed Cultural Considerations in End-of-Life Care; six questions were dedicated to Communication; one question focused on Grief, Loss, and Bereavement; and five questions were centered on Preparation and Care for The Time of Death. Question selection was based on relevance to emergency settings. Each question had four possible answers, but there was only one correct answer. Scores were computed on the percent of correct answers.

\section{Procedure}

This pilot study compared two educational approaches to increase the knowledge base of emergency department nurses on EOL care. After IRB approval was granted, six ELNEC classes were offered from September through November 2015.

Each group of nurses completed a pretest at the start of class and a posttest upon class completion and prior to completing a course evaluation. Each test took 30 minutes to complete.

Both the control and experimental groups received the aforementioned four ELNEC modules in PowerPoint presentation, participated in a case study of an actively dying homeless man who had frequented the emergency department, and viewed several video clips from ZZ Dogg MD's “Ain't the Way to Die," “Terms of Endearment: Emma's Pain Shot," and "Little Miss Sunshine: Hospital Scene.” The experimental group received the addition of simulations. 
Participants in the experimental group completed one of two simulations. The simulations involved a standardized family member, standardized physician, and a highfidelity $3 \mathrm{G} \operatorname{SimMan}{ }^{\circledR}$ and were based on real situations.

The SimMan ${ }^{\circledR}$ was programmed with vital signs and symptoms that are typical of terminally ill patients in distress. The family member and physician had scripted roles that allowed students to demonstrate communication techniques and pain and symptom management interventions.

Each simulation class was divided into two groups. Each participant went through one simulation while the other members in their group observed. After the simulations, the emergency department resident, who had played the physician in the simulations, facilitated an in-depth debriefing.

In summary, a convenience sample of emergency nurses from a Level I trauma center in California's Central Valley were recruited for a randomized controlled pilot project. Two educational approaches were compared to determine which was more effective in increasing the knowledge base of participants on EOL care. Data was analyzed to determine if there was a statistical significance between posttest scores for the lecture-only and lecture with simulation groups or between the pretest and posttest scores for the entire sample. 


\section{CHAPTER 4: RESULTS}

This chapter discusses the results of the pilot project. Data analysis entailed descriptive statistics, independent $t$-tests, and bootstrapping. The pilot project's findings and results are presented as they relate to the problem statement and research questions.

\section{Problem Statement}

The problem addressed in this study is the continuing need to find an effective approach to EOL education that would indirectly contribute to improving EOL care in the emergency setting, even though the ENA (2013) and Joint Commission (Norton, Hobson, \& Klum, 2011) have called for an increased focus on palliative and EOL care in emergency departments (Quest et al., 2011). The project's findings address the following questions:

1. Were there mean differences between baseline mean scores on EOL modules and post-ELNEC training mean scores for participants who attended the lecture with simulation courses versus participants who attended the lecture-only courses?

2. Were there mean differences between baseline mean scores on EOL modules and post-ELNEC training mean scores, separately by group?

3. Were there mean differences between baseline mean scores on EOL modules and post-ELNEC training mean scores for the whole sample?

\section{Demographics}

Fifty-three registered nurses (RNs) from the emergency department of a Level I trauma center voluntarily participated in this pilot study of two methods of teaching the ELNEC curriculum. Twenty-one percent were male while $79 \%$ were female. 
Participant years of experience in emergency nursing were categorized according to Benner's novice to expert theory. Twenty-one percent of the participants were novices having less than one year of experience. After graduation, most of the novices went directly into emergency nursing. In the years of emergency experience category, fortytwo percent of the participants had less than 3 years of experience. Years of emergency nursing experience ranged from 6 months to 33 years, with a mean of 6.2 years (Table 1). Eighty-nine percent of the participants were bedside nurses. Eleven percent assumed other roles: $5 \%$ charge nurse, $2 \%$ clinical supervisor, $2 \%$ team leader, and $2 \%$ triage nurse.

The emergency department in this setting is divided into red, yellow, green, and blue zones. The red zone is reserved for patients with life threatening conditions. This trauma zone is used to care for critical patients who have experienced a physically traumatic event. The yellow zone provides care for patients with potentially serious, but not immediately life-threatening conditions requiring moderate amount of resources. The green zone provides care for patients who are not seriously injured or ill and require minimal amount of time and resources. The blue zone, observation area, is reserved for people with low acuity who are being evaluated to determine if hospital admission is required. Fifty-one percent of nurses worked in the red/trauma zone, 19\% in the yellow zone, $23 \%$ in the green zone, and $7 \%$ in the blue zone (Table 1 ).

Table 1. Study Participant Characteristics

\begin{tabular}{|l|l|l|}
\hline Characteristic & Value $(\boldsymbol{n}=)$ & Percent \\
\hline Men & 11 & 21 \\
\hline Women & 42 & 79 \\
\hline
\end{tabular}




\begin{tabular}{|l|l|l|}
\hline Years of experience & Value $(\boldsymbol{n}=)$ & Percent \\
\hline Novice (New graduate) & 11 & 21 \\
\hline Advanced beginner $(<2$ years in ED) & 2 & 4 \\
\hline Competent $(<3$ years in ED) & 9 & 17 \\
\hline Proficient $(<5$ years in ED) & 8 & 15 \\
\hline Expert $(\geq 5$ years in ED) & 23 & 43 \\
\hline Zone Type & Value $(\boldsymbol{n}=)$ & Percent \\
\hline Red & 27 & 51 \\
\hline Yellow & 10 & 19 \\
\hline Green/Fast Track & 12 & 23 \\
\hline Blue & 4 & 7 \\
\hline Job Position & Value $(\boldsymbol{n}=)$ & Percent \\
\hline Bedside RN & 47 & 89 \\
\hline Charge RN & 3 & 5 \\
\hline Clinical supervisor & 1 & 2 \\
\hline Team leader & 1 & 2 \\
\hline Triage RN & 1 & 2 \\
\hline
\end{tabular}

Note. $\mathrm{ED}=$ emergency department; Red = immediate zone; Yellow = emergent zone; Green/Fast Track = urgent zone; Blue = trauma zone; $\mathrm{RN}=$ registered nurse. 


\section{Statistical Software and Analysis}

The data from the pretests and posttests were coded and entered into an Excel spreadsheet. Statistical analysis was conducted using SPSS 22. The assumption of homogeneity of variance, in addition to normality, was evaluated before conducting independent samples $t$-tests. Normality was evaluated by descriptive statistics, visual inspection of score distributions, and computations of normality statistics. The normality assumption clearly was violated for all studied variables.

Independent samples $t$-tests and Mann-Whitney $U$ tests were calculated to analyze group differences on the studied variables. Although the assumption of normality was violated for all EOL variables, the homogeneity of variance assumption, evaluated by Levene's test, was met for all EOL factors.

Results from the Mann-Whitney $U$ tests were very similar to those obtained from the $t$-tests. Consequently, independent samples $t$-tests, with bootstrapping, were used to analyze differences between the groups. Dependent samples t-tests, with bootstrapping, were used to analyze baseline and postscores for all studied variables, separately for each group, and for the whole sample.

Research Question 1. Were there mean differences between baseline mean scores on EOL modules and post-ELNEC training mean scores for participants who attended the lecture with simulation courses versus participants who attended the lectureonly courses? It was expected that participants who attended the lecture with simulation courses would achieve higher scores on all EOL modules than participants who only participated in lecture courses. However, the lecture group's posttest scores $(M=75.14$, $S D=9.0)$ when compared with the lecture with simulation group's posttest scores $(M=$ 
$78.56, S D=8.9)$ revealed no statistical significance $(p>.05)$. No statistical significance was noted when individual modules were compared (Table 2).

Table 2. Independent Samples t-tests of ELNEC Variables and Group

\begin{tabular}{|c|c|c|c|c|c|c|c|}
\hline \multirow[b]{3}{*}{ Study Variable } & \multicolumn{4}{|c|}{ Group } & \multirow[b]{3}{*}{$t$} & \multirow[b]{3}{*}{$p$} & \multirow[b]{3}{*}{$95 \% \mathrm{CI}$} \\
\hline & \multicolumn{2}{|c|}{ Lecture Only ${ }^{\mathrm{a}}$} & \multicolumn{2}{|c|}{$\begin{array}{l}\text { Lecture with } \\
\text { Simulation }\end{array}$} & & & \\
\hline & $M$ & $S D$ & $M$ & $S D$ & & & \\
\hline $\begin{array}{l}\text { Nursing care at } \\
\text { EOL }\end{array}$ & 2.25 & 0.70 & 2.40 & 0.71 & -0.78 & .422 & {$[-0.52,0.22]$} \\
\hline Pain management & 4.68 & 1.19 & 4.92 & 0.95 & -0.81 & .422 & {$[-0.82,-0.30]$} \\
\hline $\begin{array}{l}\text { Symptom } \\
\text { management }\end{array}$ & 2.25 & 0.80 & 2.12 & 0.78 & 0.60 & .553 & {$[-0.29,0.59]$} \\
\hline $\begin{array}{l}\text { Cultural } \\
\text { considerations in } \\
\text { EOL care }\end{array}$ & 0.89 & 0.32 & 0.84 & 0.37 & 0.56 & .577 & {$[-0.11,0.24]$} \\
\hline Communication & 4.25 & 0.70 & 4.56 & 0.92 & -1.39 & .159 & {$[-0.74,0.16]$} \\
\hline $\begin{array}{l}\text { Grief, loss, and } \\
\text { bereavement }\end{array}$ & 1.00 & 0.00 & 1.00 & - & - & - & - \\
\hline $\begin{array}{l}\text { Preparation and } \\
\text { care for the time of } \\
\text { death }\end{array}$ & 3.54 & 0.79 & 3.80 & 1.12 & -1.00 & .314 & {$[-0.73,0.26]$} \\
\hline
\end{tabular}

Note. ELNEC = End-of-Life Nursing Education Consortium; $M=$ mean; $S D=$ standard deviation; $\mathrm{CI}=$ confidence interval; $\mathrm{EOL}=$ end-of-life.

${ }^{a} n=28 .{ }^{b} n=25$. Grief, Loss, and Bereavement ${ }^{c}-t$ cannot be computed because the standard deviations of both groups are 0 . Bootstrap results are based on 1,000 bootstrap samples.

Research Question 2. Were there mean differences between baseline mean scores on EOL modules and post-ELNEC training mean scores, separately by group? Nurses who participated in lecture only courses demonstrated statistical significance on posttest scores in Nursing Care at the End of Life; Symptom Management; and Grief, Loss, and Bereavement when compared to lecture-only pretest scores (Table 3). Nurses who participated in lecture with simulation courses showed statistical significance on posttest scores in Nursing Care at the End of Life; Cultural Considerations in End of Life of Care; Grief, Loss, and 
Bereavement; and Preparation and Care for the Time of Death when compared with lecture with simulation pretest scores (Table 4).

Table 3. Dependent Samples t-tests of ELNEC Variables and Time for Lecture Only Group

\begin{tabular}{|c|c|c|c|c|c|c|c|}
\hline \multirow[b]{3}{*}{ Study Variable } & \multicolumn{4}{|c|}{ Time } & \multirow[b]{3}{*}{$t$} & \multirow[b]{3}{*}{$p$} & \multirow[b]{3}{*}{$95 \% \mathrm{CI}$} \\
\hline & \multicolumn{2}{|c|}{ Baseline $^{a}$} & \multicolumn{2}{|c|}{ Postintervention $^{\mathrm{b}}$} & & & \\
\hline & $M$ & $S D$ & $M$ & $S D$ & & & \\
\hline Nursing care at EOL & 1.64 & 0.91 & 2.25 & 0.70 & -2.50 & .017 & {$[-1.07,-0.14]$} \\
\hline Pain management & 4.46 & 0.88 & 4.68 & 1.19 & -0.80 & .440 & {$[-0.71,0.36]$} \\
\hline $\begin{array}{l}\text { Symptom } \\
\text { management }\end{array}$ & 1.64 & 0.83 & 2.25 & 0.80 & -2.76 & .014 & {$[-1.04,-0.18]$} \\
\hline $\begin{array}{l}\text { Cultural } \\
\text { considerations in } \\
\text { EOL care }\end{array}$ & 0.93 & 0.26 & 0.89 & 0.32 & 0.57 & .603 & {$[-0.17,0.18]$} \\
\hline Communication & 4.46 & 0.96 & 4.25 & 0.70 & 0.80 & .410 & {$[-0.25,0.71]$} \\
\hline $\begin{array}{l}\text { Grief, loss, and } \\
\text { bereavement }\end{array}$ & 0.64 & 0.49 & 1.00 & 0.00 & -3.87 & .004 & {$[-0.54,0.18]$} \\
\hline $\begin{array}{l}\text { Preparation and care } \\
\text { for the time of death }\end{array}$ & 3.25 & 0.75 & 3.54 & 0.79 & -1.55 & .128 & {$[-0.64,0.07]$} \\
\hline
\end{tabular}

Note. ELNEC = End-of-Life Nursing Education Consortium; $M=$ mean; $S D=$ standard deviation; $\mathrm{CI}=$ confidence interval; $\mathrm{EOL}=$ end-of-life.

${ }^{\mathrm{a}} n=28$. ${ }^{\mathrm{b}} n=28$. Grief, Loss, and Bereavement ${ }^{\mathrm{c}}-t$ cannot be computed because the standard deviations of both groups are 0 . Bootstrap results are based on 1,000 bootstrap samples.

Table 4. Dependent Samples t-tests of ELNEC Variables and Time for Lecture with Simulation Group

\begin{tabular}{|c|c|c|c|c|c|c|c|}
\hline \multirow[b]{3}{*}{ Study Variable } & \multicolumn{4}{|c|}{ Time } & \multirow[b]{3}{*}{$t$} & \multirow[b]{3}{*}{$p$} & \multirow[b]{3}{*}{$95 \% \mathrm{CI}$} \\
\hline & \multicolumn{2}{|c|}{ Baseline $^{a}$} & \multicolumn{2}{|c|}{ Postintervention $^{\mathrm{b}}$} & & & \\
\hline & $M$ & $S D$ & $M$ & $S D$ & & & \\
\hline $\begin{array}{l}\text { Nursing care at the } \\
\text { EOL }\end{array}$ & 1.88 & 1.01 & 2.40 & 0.71 & 1.96 & .015 & {$[-1.32,-0.24]$} \\
\hline Pain management & 4.12 & 1.01 & 4.92 & 0.95 & 2.83 & .147 & {$[-0.72,0.08]$} \\
\hline $\begin{array}{l}\text { Symptom } \\
\text { management }\end{array}$ & 1.80 & 0.76 & 2.12 & 0.78 & 1.50 & .354 & {$[-0.72,0.59]$} \\
\hline Cultural & 0.60 & 0.50 & 0.84 & 0.37 & - & .038 & {$[-0.40,-0.08]$} \\
\hline
\end{tabular}


considerations in 2.75

EOL Care

Communication

Grief, loss, and

bereavement

Preparation and care for the time of death

$$
4.32 \quad 0.99
$$$$
0.40 \quad 0.50
$$

$2.80 \quad 1.19$
4.56

$1.00 \quad 0.00$

3.80

0.92

$0 . \overline{5}$

.354

$[-0.72,0.24]$

6.00

.001

$[-0.80,-0.40]$

Note. ELNEC = End-of-Life Nursing Education Consortium; $M=$ mean; $S D=$ standard deviation; $\mathrm{CI}=$ confidence interval; $\mathrm{EOL}=$ end-of-life.

${ }^{\mathrm{a}} n=25$. ${ }^{\mathrm{b}} n=25$. Bootstrap results are based on 1,000 bootstrap samples.

Research Question 3. Were there mean differences between baseline mean

scores on EOL modules and post-ELNEC training mean scores for the whole sample?

Statistical significance was demonstrated on posttest scores for all scales of EOL

modules, except for Communication and Cultural Considerations in EOL Care when

compared with pretest scores (Table 5).

Table 5. Dependent Samples t-tests of ELNEC Variables and Time for the Whole Sample

\begin{tabular}{|c|c|c|c|c|c|c|c|}
\hline \multirow[b]{3}{*}{ Study Variable } & \multicolumn{4}{|c|}{ Time } & \multirow[b]{3}{*}{$t$} & \multirow[b]{3}{*}{$p$} & \multirow[b]{3}{*}{$95 \% \mathrm{CI}$} \\
\hline & \multicolumn{2}{|c|}{ Baseline $^{a}$} & \multicolumn{2}{|c|}{ Postintervention ${ }^{\mathrm{b}}$} & & & \\
\hline & $M$ & $S D$ & $M$ & $S D$ & & & \\
\hline $\begin{array}{l}\text { Nursing care at the } \\
\text { EOL }\end{array}$ & 1.75 & 0.96 & 2.32 & 0.70 & -3.19 & .003 & {$[-0.89,-0.23]$} \\
\hline Pain management & 4.30 & 0.95 & 4.79 & 1.08 & -2.49 & .016 & {$[-0.85,-0.08]$} \\
\hline $\begin{array}{l}\text { Symptom } \\
\text { management }\end{array}$ & 1.72 & 0.79 & 2.19 & 0.79 & -3.07 & .003 & {$[-0.78,-0.17]$} \\
\hline $\begin{array}{l}\text { Cultural } \\
\text { considerations in } \\
\text { EOL Care }\end{array}$ & 0.77 & 0.42 & 0.87 & 0.34 & -1.70 & .125 & {$[-0.21,0.02]$} \\
\hline Communication & 4.40 & 0.97 & 4.40 & 0.82 & 0.00 & 1.00 & {$[-0.36,0.38]$} \\
\hline $\begin{array}{l}\text { Grief, loss, and } \\
\text { bereavement }\end{array}$ & 0.53 & 0.50 & 1.00 & 0.00 & -6.81 & .001 & {$[-0.62,-0.34]$} \\
\hline $\begin{array}{l}\text { Preparation and care } \\
\text { for the time of death }\end{array}$ & 3.04 & 1.00 & 3.66 & 0.96 & -3.17 & .005 & {$[-1.00,-0.23]$} \\
\hline
\end{tabular}


Note. ELNEC $=$ End-of-Life Nursing Education Consortium; $M=$ mean; $S D=$ standard deviation; $\mathrm{CI}=$ confidence interval; $\mathrm{EOL}=$ end-of-life.

${ }^{\mathrm{a}} n=53 .{ }^{\mathrm{b}} n=53$. Bootstrap results are based on 1,000 bootstrap samples.

When compared, the lecture only and lecture with simulation groups showed no statistical significance between groups. However, when modules were examined individually, statistical significance was demonstrated in both groups for the Nursing care at the EOL, Pain management, Symptom management, Grief, loss, and bereavement, and Preparation and care for the time of death modules. 


\section{CHAPTER 5: DISCUSSION}

This chapter examines the results of the comparison of the effectiveness of two educational approaches to teaching the ELNEC course. The limitations of the pilot project include class format, sample size, project setting, and the use of non-validated tools. Finally, recommendations and implications for further study are examined.

\section{Summary of Findings}

Increasingly, emergency nurses are caring for patients with more chronic illness burden requiring palliative or EOL care in the emergency department setting. However, the literature has shown that emergency nurses are not always comfortable providing this type of care. Providing effective education can improve EOL care in emergency departments.

The purpose of this project was to compare two teaching methods using ELNEC material in a class designed specifically for emergency nurses. The project's focus was unique because it examined EOL care in a Level I trauma center that treats 311 patients per day on average. This setting presented different perspectives of the barriers to EOL care.

Each instructional module was interpreted separately for statistical significance for the entire sample. Results indicate that no statistical significance was found between the two teaching methods for any of the modules. However, an increased knowledge base was noted for the entire sample in five of the seven modules, Nursing Care at the End of Life; Pain Management; Symptom Management; Grief, Loss and Bereavement; and Preparation and Care for the Time of Death. Cultural Consideration in End-of-Life 
Care may not have reached statistical significance because only one test question was taken from this content area.

Although there was a statistically significant $16 \%$ increase from pretest to posttest scores, this pilot project aligned with what is reported in that literature, emergency nurses find this content difficult to embrace (Norton et al., 2011; Sherman et al., 2005). Participants identified communication with physicians, patients, and families as one of their greatest challenges. However, posttest scores indicated that the communication content was not comprehended well in either of the groups, even though the simulation group had a scenario dedicated to communication.

Communication challenges in EOL care have been identified in the literature (Blackhall, Erickson, Brashers, Owen, \& Thomas, 2014; Boyle, Miller, \& ForbesThompson, 2005; Reinke et al., 2011; Wittenberg, Goldsmith, \& Neiman, 2015) and may be due to how little interprofessional education nurses and physicians receive (Blackhall et al., 2014). In order to improve communication in EOL care situations, instructional time should be increased and the topic offered more frequently. Validated scenarios would enhance all content areas.

The average years of nursing experience in this setting was $M=6.21$. Forty-two percent of the participants had less than 3 years' experience in an emergency department, which is considered competent according to Benner's novice to expert theory (Benner, 1982). Less time in an emergency department may indicate fewer opportunities to care for EOL patients. Nurses with less experience find EOL communication particularly difficult because they are still trying to refine basic nursing skills (Barrere \& Durkin, 2014). Because these nurses may not have receive adequate EOL education in their 
undergraduate program, their knowledge base may have been considerably lower coming into class (Ferrell \& Coyle, 2002; Gillan et al., 2014a; Schlairet, 2009). Fifteen percent had more than 3 years of experience, which according to Benner (1982) is proficient. Forty-three percent of the participants had more than 5 years of experience, which Benner considers expert level.

Only six percent of the participants had leadership positions in addition to their role as a bedside nurse. These leadership positions within the emergency department may have given the nurses more experience in communication between physicians and family members. When in this role, the nurse is expected to be resources to the bedside nurses. A trauma center is a highly specialized setting that handles extreme cases of life or death. Rural or county hospital emergency departments may have shown different results. We were seeking to increase emergency nurses' knowledge of EOL care so that they could deliver more effective, empathic care to dying patients. But changing how nurses perform may not be the best solution. Although we would not expect palliative care nurses to competently care for trauma patients, we should not expect trauma nurses to competently care for EOL patients. The appropriate specialty should be assigned to the right type of patients to ensure better patient outcomes. After this project, palliative care referrals increased considerably in this setting.

The high-fidelity SimMan ${ }^{\circledR}$ allowed students to demonstrate the knowledge they acquired of evidence-based interventions for pain and symptoms common in actively dying patients. The standardized family member and physician allowed students to use communication strategies. The expectation was that the application of acquired knowledge would enable participants to score higher on the posttest. 


\section{Limitations}

Since the participants were encouraged to have open dialogue, ensuring that each class received the same exact content was difficult. A particular class may have had one topic discussed more than other classes. All participants were recruited from a Level I trauma center and work in a culture where saving the lives of people in critical and often hopeless situations is constant. This may impart a natural bias that is more challenging to overcome, making the transformative learning process more difficult to achieve in a short amount of time.

In addition, the zone a nurse worked in could have inhibited their ability to relate to this topic. Thirty percent of the participants worked in the blue and green zones. Subsequently, nurses working in these zones provide care for lower acuity patients and may not have been exposed to many EOL situations. Furthermore, the $51 \%$ of nurses who worked in the red/trauma zone were immersed in the day-to-day culture of saving lives and may not have identified the acuity of the actively dying patient. . Only $19 \%$ of participants worked in the yellow zone, which is the only zone where EOL patients were consistently admitted.

Another limitation was the small sample size . A power calculation indicated that the sample size should be no less than 134. The small sample may have increased the risk of Type II errors, leading to a false negative conclusion (Polit \& Beck, 2006). Finally, the author acknowledges that the modified ELNEC-Knowledge Assessment Test was not a validated instrument. There was no pilot study conducted to validate the modified tool. 


\section{Recommendations for Future Research}

Nurses believe that improved communication with physicians, patients, and family members is required to improve EOL care in emergency departments (Chan, 2006; Eby, 2008; Smith et al., 2010). Further development and testing of interventions to improve communication between staff, patients, and family members should be considered. This might be achieved with classes on communication at EOL with validated communication simulations.

The effects of lecture versus lecture with simulation over time should be explored. One method might help participants retain EOL knowledge better than the other. A larger sample with a diverse setting of emergency departments, such as rural and county hospitals, may create more generalizable results.

One of the most beneficial consequences of this course was that palliative care consults increased after participants completed this course. Thus, a class that provides palliative and EOL resources to emergency departments may prove valuable to staff. Tracking how the application of knowledge from the ELNEC course affects EOL care in an emergency department would show the efficacy of the course.

\section{Implications for Practice}

Despite this project's limitations and that no statistical significance was found between the two educational methods, the sample's increased knowledge base addressed the need for emergency nurses to receive EOL education (Quest, et al., 2011). Most previous studies of EOL simulation involved nursing students (Leighton \& Dubas, 2009; Fluharty et al., 2012; Tuxbury, McCauley, \& Lement, 2012). Although simulation for practicing nurses has increased (Aebersold \& Tschannen, 2013), the literature lacked 
studies that examined EOL simulations with practicing nurses. This project served to close the gap between the uses of simulation at nursing schools versus with practicing nurses. This may serve to prompt the more use of simulation in the practice setting. Furthermore, the debriefings from the simulations will allow emergency nurses to modify their behavior in EOL situations. Finally, placing palliative care nurses in emergency departments as a permanent resource may increase the quality of EOL care.

\section{Conclusion}

As terminally ill patients continue to use emergency departments for pain and symptom management and EOL care, emergency staff must be provided with educational opportunities and resources on EOL care. The ELNEC course is one method of increasing the EOL knowledge base of nurses. The purpose of this pilot project was to compare two methods of instruction to determine which was more effective in improving the knowledge base of emergency nurses on EOL care. Although no statistical significance was found between the lecture only and the lecture with simulation group, the entire sample showed statistical significance in its increased knowledge of EOL care. 
REFERENCES 


\section{REFERENCES}

Aerbersold, M., \& Tschannen, D. (2013). Simulation in nursing practice: The impact on patient care. Retrieved from http://nursingworld.org/MainMenuCategories/ANAMarketplace/ANAPeriodicals/OJIN/T ableofContents/Vol-18-2013/No2-May-2013/Simulation-in-Nursing-Practice.html

American Association of Colleges of Nursing. (2012). End-of-life nursing education consortium (ELNEC): History, statewide effort and recommendations for the future. Retrieved from http://www.aacn.nche.edu/elnec/publications/ELNEC-Monograph.pdf

American Association of Colleges of Nursing. (2016). AACN takes action to enhance end-of-life nursing care. Retrieved from http://www.aacn.nche.edu/news/articles/2016/elnec

Barrere, C., \& Durkin, A. (2014). Finding the right words: The experience of new nurses after ELNEC education integration into a BSN curriculum. MEDSURG Nursing, 23(1), 35-53.

Beckstrand, R. L., Giles, V. C., Luthy, K. E., Callister, L. C., \& Heaston, S. (2012). The last frontier: Rural emergency nurses' perceptions of end-of-life care obstacles. Journal of Emergency Nursing, 38(5), e15-e25. doi:10.1016/j.jen.2012.01.003

Beckstand, R. L., Rasmussen, R. J., Luthy, K. E., \& Heaston, S. (2012). Emergency nurses’ perception of department design as an obstacle to providing end-of-life care. Journal of Emergency Nursing, 38(5), 27-32. doi:10.1016/j.jen.2011.12.019

Beckstrand, R. L., Wood, R. D., Callister, L. C., Luthy, K. E., \& Heaston, S. (2012). Emergency nurses’ suggestions for improving end-of-life-care obstacles. Journal of Emergency Nursing, 38(5), e7-e14. doi:10.1016/j.jen.2012.03.008 
Benner, P. (1982). From novice to expert. The American Journal of Nursing, 82(3), 402-407.

Blackhall, L. J., Erickson, J., Brashers, V., Owen, J., \& Thomas, S. (2014). Development and validation of a collaborative behaviors objective assessment tool for end-of-life communication. Journal of Palliative Medicine, 17(1), 68-74.

doi:10.1089/jpm.2013.0262

Boyle, D. K., Miller, P. A., \& Forbes-Thompson, S. A. (2005). Communication and end-of-life care in the intensive care unit. Critical Care Nursing Quarterly, 28(4), 302-316.

Bussman, S., Muders, P., Zahrt-Omar, C. A., Escobar, P. L., Claus, M., Schildmann, J., \& Weber, M. (2015). Improving end-of-life care in hospitals: A qualitative analysis of bereaved families' experiences and suggestions. American Journal of Hospice \& Palliative Medicine, 32(1), 44-51. doi:10.1177/1049909113512718

Carr, D. (2012). Death and dying in the contemporary United States: What are the psychological implications of anticipated death? Social and Personality Psychology Compass, 6(2), 184-195. doi:10.1111/j.1751-9004.2011.00416.x

Cassel, C. K., \& Foley, K. M. (1999). Principles for care of patients at the end of life: An emerging consensus among the specialties of medicine. Retrieved from http://www.milbank.org/uploads/documents/endoflife/\#core

Centers for Disease Control and Prevention. (2010). National hospital ambulatory medical care survey: 2010 emergency department summary tables. Retrieved from http://www.cdc.gov/nchs/data/ahcd/nhamcs_emergency/2010_ed_web_tables.pdf

Chan, G. K. (2006). End-of-life and palliative care in the emergency department: A call for research, education, policy and improved practice in this frontier area. Journal of Emergency Nursing, 32(1), 101-103. doi:10.1016/j.jen.2005.10.006 
Chan, G. K., Bryant, E. N., Lambda, S., Weissman, D. E., Quest, T. E., \& Todd, K. H. (2011). Clinical practice guidelines: A technical assistance resource from the IPAL-EM project. Retrieved from https://www.capc.org/ipal/ipal-emergency-medicine/

Eby, K. J. (2008). Palliative care and the emergency department. Journal of Hospice \& Palliative Nursing, 10(2), 73-75. doi:10.1097/01.njh.0000306726.55484.e9

Emergency Nurses Association. (2013). Palliative and end-of-life care in the emergency setting. Retrieved from https://www.ena.org/SiteCollectionDocuments/Position\%20Statements/PalliativeEndOfL ifeCare.pdf

Fluharty, L., Hayes, A. S., Milgrom, L., Malarney, K., Smith, D., Reklau, M.A.,...McNelis, A. M. (2012). A multisite, multi-academic track evaluation of end-of-life simulation for nursing education. Clinical Simulation in Nursing, 8(4), e135-e143. doi:10.1016/j.ecns.2010.08.003

Gillan, P. C., van der Riet, P. J., \& Jeong, S. (2014a). End of life care education, past and present: A review of literature. Nursing Education Today, 34(3), 331-342. doi:10.1016/j.nedt.2013.06.009

Gillan, P. C., van der Riet, P. J., \& Jeong, S. (2014b). End of life care simulation: A review of literature. Nurse Education Today, 34(5), 766-774. doi:10.1016/j.nedt.2013.10.005

Glazer, H. R., \& Stein, D. (2015). Mindfulness and the play-therapist supervisor: A study in transformative learning. International Journal of Play Therapy, 24(1), 41-53. doi:http://dx.doi.org/10.1037/a0038663 
Grudzen, C. R., Stone, S. C., \& Morrison, R. S. (2011). The palliative care model for emergency department patients with advanced illness. Journal of Palliative Medicine, 14(8), 945950. doi:10.1089/jpm.2011.0011

Hayes, C. (2015). Meaning-making through transformative learning for HCA education. British Journal of Healthcare Assistants, 9(7), 354-361. doi:http://dx.doi.org/10.12968/bjha.2015.9.7.354

Heaston, S., Beckstrand, R. L., Bond, A. E., \& Palmer, S. P. (2006). Emergency nurses' perceptions of obstacles and supportive behaviors in end-of-life care. Journal of Emergency Nursing, 32(6), 477-485. doi:10.1016/j.jen.2006.07.013

Hui, D., De La Cruz, M., Mori, M., Parsons, H. A., Kwon, J. H., Torres-Vigil, I.,...Bruera, E. (2013). Concepts and definitions for "supportive care," "best supportive care," "palliative care," and "hospice care" in published literature, dictionaries, and textbooks. Supportive Care in Cancer, 21(3), 659-685. doi:10.1007/s00520-012-1564-y

Hui, D., Nooruddin, Z., Didwaniya, N., Dev, R., De La Cruz, M., Kim, S. H.,...Bruera, E. (2014). Concepts and definitions for "actively dying," “end of life," "terminally ill," "terminal care," and "transition of care": A systematic review. Journal of Pain and Symptom Management, 47(1), 77-89. doi:10.1016/j.jpainsymman.2013.02.021

Institute of Medicine. (2015). Dying in America: Improving quality and honoring individual preferences near the end of life (2015) [Summary]. Retrieved from http://www.nap.edu/read/18748/chapter/2

Jeffers, S. (2014). Nurse faculty perceptions of end-of-life education in the clinical setting: A phenomenological perspective. Nurse Education in Practice, 14(5), 455-460. doi:10.1016/j.nepr.2014.03.009 
Lamba, S., \& Quest, T. E. (2011). Hospice care and the emergency department: Rules, regulations, and referrals. Annals of Emergency Medicine, 57(3), 282-290. doi:10.1016/j.annemergmed.2010.06.569

Lange, J. W., Shea, J., Grossman, S. C., Wallace, M., \& Ferrell, B. R. (2009). Validation of the end-of-life nursing education consortium knowledge assessment test: An abbreviated version. Journal of Hospice and Palliative Nursing, 11(5), 284-290.

Leighton, K., \& Dubas, J. (2009) Simulated death: An innovative approach to teaching end-oflife care. Clinical Simulation in Nursing, 5(6), e223-e230. doi:http://dx.org/10.1016/j.ecns.2009.04.093

Mayo Clinic. (2014). End of life: Caring for a dying loved one. Retrieved from http://www.mayoclinic.org/healthy-living/end-of-life/in-depth/cancer/art-20047600

Meier, D. E. (2011). Increased access to palliative care and hospice services: Opportunities to improve value in health care. Milbank Quarterly, 89(3), 343-380. doi:10.1111/j.14680009.2011.00632.x

Mezirow, J. (2009). An overview on transformative learning. In K. Illeris (Ed.), Contemporary theories of learning: Learning theorists...in their own words (pp. 90-105). Abingdon, Oxon, England: Routledge. Retrieved from http://www.pgce.soton.ac.uk/IT/Learning/Theories/ContemporaryTheoriesofLearning\%2 0Learning\%20theorists\%20in\%20their\%20own\%20words\%20-\%20Knud\%20Illeris.pdf National Hospice and Palliative Care Organization. (2013). NHPCO's facts and figures: Hospice care in America. 2013 edition. Retrieved from http://www.nhpco.org/sites/default/files/public/Statistics_Research/2013_Facts_Figures.p df 
Norton, C. K., Hobson, G., \& Kulm, E. (2011). Palliative and end-of-life care in the emergency department: Guidelines for nurses. Journal of Emergency Nursing, 37(3), 240-245. doi:10.1016/j.jen.2010.02.019

Paice, J.A., Ferrell, B.R., Virani, R., Grant, M., Malloy, P., \& Rhome, A. (2006). Appraisal of the graduate End-of-Life Nursing Education Training Program. Journal of Palliative Medicine, 9(2), 353-360.

Polit, D. F., \& Beck, C. T. (2006). Essentials of nursing research: Methods, appraisal, and utilization (6th ed.). Philadelphia, PA: Lippincott Williams \& Wilkins.

Quest, T. E., Asplin, B. R., Cairns, C. B., Hwang, U., \& Pines, J. M. (2011). Research priorities for palliative care in the emergency setting. Academy of Emergency Medicine, 18(6), e70e76. doi:10.1111/j.1553-2712.2011.01088.x

Quest, T., Herr, S., Lambda, S., \& Weissman, D. (2013). Demonstrations of clinical initiatives to improve palliative care in the emergency department: A report from the IPAL-EM initiative. Annals of Emergency Medicine, 61(6), 661-667. doi:10.1016/j.annemergmed.2013.01.019

Reinke, L. F., Slatore, C. G., Uman, J., Udris, E. M., Moss, B. R., Engelberg, R. A. \& Au, D. H. (2011). Patient-clinician communication about end-of-life care topics: Is anyone talking to patients with chronic pulmonary disease? Journal of Palliative Medicine, 14(8), 923928. doi:10.1089/jpm.2010.0509

Schlairet, M. C. (2009). End-of-life nursing care: Statewide survey of nurses' education needs and effects of education. Journal of Professional Nursing, 25(3), 170-177. doi:10.1016/j.profnurs.2008.10.005 
Shea, J., Grossman, S., Wallace, M., \& Lange, J. (2010). Assessment of advanced practice palliative care nurse competencies in nurse practitioner students: Implications for the integration of ELNEC curricular modules. Journal of Nursing Education, 49(4), 183-189. doi:10.3928/01484834-20090915-05

Sherman, D. W., Matzo, M. L, Rogers, S., McLaughlin, M., \& Virani, R. (2005). Achieving quality care at the end-of-life: A focus of the end-of-life nursing education consortium (ELNEC) curriculum. Journal of Professional Nursing, 18(5), 255-262. doi:10.1053/jpnu.2002.129229

Smith, A. K., Schonberg, M. A., Fisher, J., Pallin, D. J., Block, S. D., Forrow, L., \& McCarthy, E. P. (2010). Emergency department experiences of acutely symptomatic patients with terminal illness and their family caregivers. Journal of Pain and Symptom Management, 39(6), 972-981. doi:10.1016/j.jpainsymman.2009.10.004

Smith, A., McCarthy, E., Weber, E., Cenzer, I. S., Boscardin, J., Fisher, J., \& Covinsky, K. (2012). Half of older Americans seen in emergency department in last month of life; Most admitted to hospital, and many die there. Health Affairs, 31(6), 1277-1285. doi:10.1377/hlthaff.2011.0922

Tuxbury, J. S., McCauley, P. M., \& Lement, W. (2012). Nursing and theatre collaborate: An end-of-life simulation using forum theatre. Journal of Nursing Education, 51(8) 462-465. doi:10.3928/01484834-20120615-02

University of California, San Francisco. (2015). Hospitals: Community regional medical center. Retrieved from http://www.fresno.ucsf.edu/em/hospitals.htm 
University of Central Oklahoma. (2012a). Transformative learning. Teaching strategies for transformative learning. Retrieved from https://www.uco.edu/academicaffairs/cettl/TLGuideFiles/2012-05-tl.pdf

University of Central Oklahoma. (2012b). Transformative learning. What is transformative learning? (Pt.1). Retrieved from https://www.uco.edu/academicaffairs/cettl/TLGuideFiles/2012-03-tl.pdf

White, K. R., \& Coyne, P. J. (2011). Nursing perceptions of educational gaps in delivering endof-life care. Oncology Nursing Forum, 38(6), 711-717. doi:10.1188/88/11.ONF.711-717

White, K. R., Coyne, P. J., \& Patel, U. B. (2001). Are nurses adequately prepared for end-of-life care? Journal of Nursing Scholarship, 33(2), 147-151.

Wittenberg, E., Goldsmith, J., \& Neiman, T. (2015). Nurse-perceived communication challenges and roles on interprofessional care teams. Journal of Hospice \& Palliative Nursing, 17(3), 257-262. doi:10.1097/NJH.0000000000000160

World Health Organization. (2014). Palliative care is an essential part of cancer control. Retrieved from http://www.who.int/cancer/palliative/en/ 
APPENDICES 
APPENDIX A: EMAIL TO PARTICIPANTS 
Dear

Proving end-of-Life care in the emergency department can prove difficult due to:

- poor communication

- lack of time

- resources

- privacy

- staffing issues

- increased census

Despite these challenges, evidence shows that the terminally ill population and their family members will continue to utilize the emergency department for end-of-life and palliative services. Therefore, it is essential that emergency staff is able to care for this population in the most efficient and effective manner possible.

End-of-Life Nursing Education Consortium (ELNEC) classes have been designed to specifically meet the unique challenges that have been identified in the CRMC ED. Eight CEUs and lunch will be provided. This class is voluntary however; if you opt to enroll it will be a paid education day.

Classes limited to 10 participants per day and will be held from 0800 to 1600 in the $3 \mathrm{~A}$ Classroom ( $3^{\text {rd }}$ floor annex).

- Monday- Sept 14, 2015

- Monday- Sept 21, 2015

- Friday- October 2,2915

- Wednesday- October 7, 2015

- Wednesday -November 4, 2015

- Friday - November 6, 2015

This class is part of a study to determine the most effective method to provide end-of-life education to emergency staff

Please review details of the study attached, and enroll in HealthStream under ED ELNEC by $09 / 10 / 2015$ if you are interested.

\section{Registering for Class}

1. In HLC go to "Catalog"

2. Type in the course identifier or course name: "ED ELNEC"

3. Click on "Search"

4. Click on the course link

5. Click on "Show Class Schedule".(DO NOT click on) "Enroll in this Course"

6 . The list of classes will appear. To register for the class, click on "Register" to the far right.

7. Status should show "Registered" 


\section{APPENDIX B: INFORMED CONSENT}


A comparison of instructional approaches to End-of-Life Nursing Education Consortium (ELNEC) training. A pilot study.

You have been invited to participate in a research study to compare the effectiveness of two different learning strategies for end-of-life education. Your participation is voluntary and there will be no repercussions if you chose not to participate in this study. The Principal Investigator is Jennifer Bodine.

If you agree to be involved with the study you will be randomized into one of two groups. One group will participate in an ELNEC lecture and discussion training. The other group will participate in an ELNEC lecture and discussion training with simulation. At the beginning of training you will be given a pretest and upon completion of the education you will be assessed with a posttest.

The education will take approximately 6.5 hours and the simulation will take approximately 30 minutes. The education will occur at Community Regional Medical Center (CRMC) on 09/14/15, 09/21/15, 10/02/15, 10/07/15, 11/04/15, and 11/06/15 from $8 \mathrm{am}-4 \mathrm{pm}$.

The study will start with a pretest at 0830 and the posttest will be completed by $4 \mathrm{pm}$.

Some participants may feel stressed performing in a simulated environment. This potential risk will be mitigated by allowing you to leave the study at any time. Additionally, a prebriefing and debriefing will occur prior to and following the simulation to allow you to ask questions or express concern. Scores of the pretest and posttest and performance in the simulated environment will be confidential. Names will not be used on the assessment tools. Data will be protected using a password protected computer system that can only be accessed by the Principal Investigator.

\section{Benefits}

The education will provide you with evidence-based information regarding the current recommendations relating to end-of-life care. This pilot study assists in identifying the most feasible and effective learning strategy for end-of-life care and is the next phase in an organizational initiative with the goal of improving the quality of end-of-life care delivered in the emergency department.

This project has been approved by the Human Subjects Institutional Review Boards at Community Regional Medical Center. It has also been approved by the School of Nursing, Human Subjects Institutional Review Board, California State University, Fresno as this project will contribute towards completion of the Principal Investigators Doctorate in Nursing Practice.

Any questions and concerns about rights as a research subject should be directed to the Committee for the Protection of Human Subjects: Manager, (CRMC) Lisa Foster (559)499-6552; Chair, (Fresno State) Terea Giannetta (559) 278-2808. 
Your decision to complete the education and assessment constitutes informed consent. If you have any questions regarding this study please contact, Jennifer Bodine, by email at jbodine@,fresnoheartandsurgical.org or call 559-260-7328. 
APPENDIX C: MODIFIED ELNEC TEST 
Code \#

\section{EMERGENCY NURSES' PERCEPTIONS OF END-OF-LIFE CARE}

The end of life is currently being recognized as an important life phase. Emergency nurses are frequently responsible for care of patients who are at the end of life and dying. Care dilemmas arise for nurses as dying patients are in an environment created to emergently support life.

The following items pertain to your perceptions of possible obstacles to providing end-of.life care to dying patients and their families. As you read each item, please mark the circle that most closely characterizes how large an obstacle you have found each item to be then mark the box for how frequently you have experienced the obstacle as you have cared for dying patients.

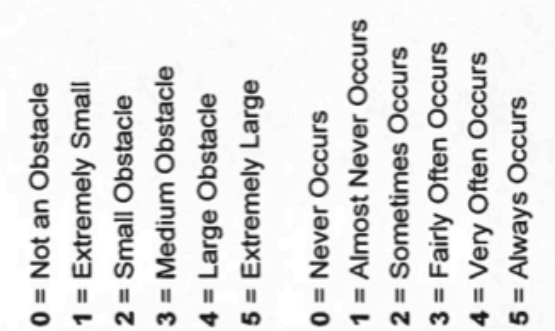

\begin{tabular}{|c|c|c|c|}
\hline 1. & $\begin{array}{l}\text { The nurse not being comfortable caring for dying patients } \\
\text { and/or their families. }\end{array}$ & $\begin{array}{llllll}0 & 1 & 2 & 3 & 4 & 5 \\
\bigcirc & \bigcirc & \bigcirc & \bigcirc & \bigcirc & \bigcirc\end{array}$ & 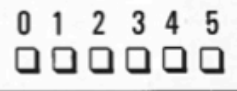 \\
\hline 2. & $\begin{array}{l}\text { Families not accepting what the physician is telling them about } \\
\text { the patient's poor prognosis. }\end{array}$ & $\begin{array}{llllll}0 & 1 & 2 & 3 & 4 & 5 \\
\bigcirc & \bigcirc & \bigcirc & \bigcirc & \bigcirc & \bigcirc\end{array}$ & $\begin{array}{llllll}0 & 1 & 2 & 3 & 4 & 5 \\
\square & \square & \square & \square\end{array}$ \\
\hline 3. & $\begin{array}{l}\text { The nurse having to deal with distraught family members while } \\
\text { still providing care for the patient. }\end{array}$ & $\begin{array}{llllll}0 & 1 & 2 & 3 & 4 & 5 \\
\bigcirc & \bigcirc & \bigcirc & \bigcirc & \bigcirc & \end{array}$ & 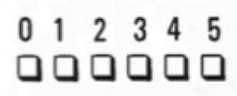 \\
\hline 4. & $\begin{array}{l}\text { Intra-family disagreements about whether to approve the use } \\
\text { of life support. }\end{array}$ & $\begin{array}{llllll}0 & 1 & 2 & 3 & 4 & 5 \\
\bigcirc & \bigcirc & \bigcirc & \bigcirc & \bigcirc & \bigcirc\end{array}$ & $\begin{array}{l}012345 \\
\text { ロロロロロ }\end{array}$ \\
\hline 5. & $\begin{array}{l}\text { When the nurses' opinion about the direction patient care } \\
\text { should go is not requested, not valued, or not considered. }\end{array}$ & $\begin{array}{llllll}0 & 1 & 2 & 3 & 4 & 5 \\
\bigcirc & \bigcirc & \bigcirc & \bigcirc & \end{array}$ & $\begin{array}{lllll}0 & 1 & 2 & 3 & 4 \\
\square & \square & \square & \end{array}$ \\
\hline 6. & $\begin{array}{l}\text { Not enough time to provide quality end-of-life care because the } \\
\text { nurse is consumed with activities that are trying to save the } \\
\text { patient's life. }\end{array}$ & $\begin{array}{llllll}0 & 1 & 2 & 3 & 4 & 5 \\
\bigcirc & \bigcirc & \bigcirc & \bigcirc & \bigcirc & \bigcirc\end{array}$ & $\begin{array}{llllll}0 & 1 & 2 & 3 & 4 & 5 \\
\square & \square & \square & \square\end{array}$ \\
\hline 7. & $\begin{array}{l}\text { Poor design of emergency departments which do not allow for } \\
\text { privacy of dying patients or grieving family members. }\end{array}$ & $\begin{array}{llllll}0 & 1 & 2 & 3 & 4 & 5 \\
\bigcirc & \bigcirc & \bigcirc & \bigcirc & \bigcirc & \bigcirc\end{array}$ & $\begin{array}{lllll}0 & 1 & 2 & 3 & 4 \\
\square & \square & \square & \square\end{array}$ \\
\hline 8. & $\begin{array}{l}\text { Restriction of family members in the ED room during } \\
\text { resuscitation. }\end{array}$ & $\begin{array}{llllll}0 & 1 & 2 & 3 & 4 & 5 \\
\bigcirc & \bigcirc & \bigcirc & \bigcirc & \bigcirc & \bigcirc\end{array}$ & 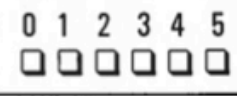 \\
\hline 9. & The patient having pain that is difficult to control or alleviate. & $\begin{array}{llllll}0 & 1 & 2 & 3 & 4 & 5 \\
\bigcirc & \bigcirc & \bigcirc & \bigcirc & \bigcirc & \bigcirc\end{array}$ & 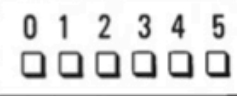 \\
\hline 10. & $\begin{array}{l}\text { Dealing with the cultural differences that families employ in } \\
\text { grieving for their dying family member. }\end{array}$ & $\begin{array}{llllll}0 & 1 & 2 & 3 & 4 & 5 \\
\bigcirc & \bigcirc & \bigcirc & \bigcirc & \bigcirc & \bigcirc\end{array}$ & 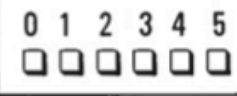 \\
\hline 11. & $\begin{array}{l}\text { No available support person for the family such as a social } \\
\text { worker or religious leader. }\end{array}$ & $\begin{array}{llllll}0 & 1 & 2 & 3 & 4 & 5 \\
\bigcirc & \bigcirc & \bigcirc & \bigcirc & \bigcirc & \bigcirc\end{array}$ & 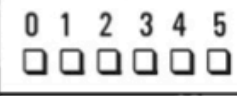 \\
\hline 12. & $\begin{array}{l}\text { Employing life sustaining measures at the families' request } \\
\text { even though the patient had signed advanced directives } \\
\text { requesting no such treatment. }\end{array}$ & $\begin{array}{llllll}0 & 1 & 2 & 3 & 4 & 5 \\
\bigcirc & \bigcirc & \bigcirc & \bigcirc & \bigcirc & \bigcirc\end{array}$ & $\begin{array}{llllll}0 & 1 & 2 & 3 & 4 & 5 \\
\square & \square & \square & \square\end{array}$ \\
\hline
\end{tabular}

C Beckstrand 2011 Page -1- 
The following items pertain to your perceptions of possible obstacles to providing end.of-life care to dying patients and their families. As you read each item, please mark the circle that most closely characterizes how large an obstacle you have found each item to be then mark the box for how frequently you have experienced the obstacle as you have cared for dying patients.

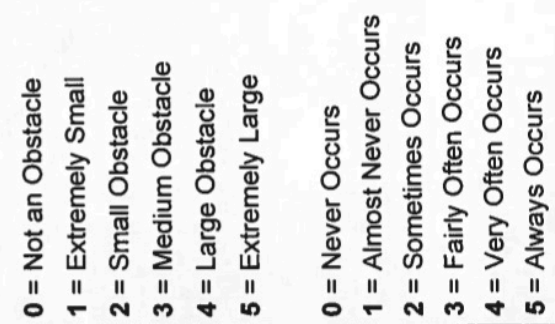

\begin{tabular}{|c|c|c|c|}
\hline 13. & $\begin{array}{l}\text { Continuing resuscitation for a patient with a poor prognosis } \\
\text { because of the real or imagined threat of future legal action } \\
\text { by the patient's family. }\end{array}$ & $\begin{array}{llllll}0 & 1 & 2 & 3 & 4 & 5 \\
\bigcirc & \bigcirc & \bigcirc & \bigcirc & \bigcirc & \bigcirc\end{array}$ & $\begin{array}{llllll}0 & 1 & 2 & 3 & 4 & 5 \\
\square & \square & \square & \square\end{array}$ \\
\hline 14. & $\begin{array}{l}\text { Pressure to limit family grieving after the patient's death to } \\
\text { accommodate a new admit to that room. }\end{array}$ & $\begin{array}{llllll}0 & 1 & 2 & 3 & 4 & 5 \\
\bigcirc & \bigcirc & \bigcirc & \bigcirc & \bigcirc & \bigcirc\end{array}$ & 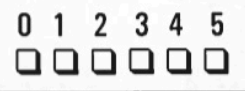 \\
\hline 15. & $\begin{array}{l}\text { Providing treatments for a dying patient even though the } \\
\text { treatments cause the patient pain or discomfort. }\end{array}$ & $\begin{array}{llllll}0 & 1 & 2 & 3 & 4 & 5 \\
\bigcirc & \bigcirc & \bigcirc & \bigcirc & \bigcirc & \bigcirc\end{array}$ & $\begin{array}{llllll}0 & 1 & 2 & 3 & 4 & 5 \\
\square & \square & \square & \square & \square\end{array}$ \\
\hline 16. & $\begin{array}{l}\text { Family and friends who continually call the nurse wanting an } \\
\text { update on the patient's condition rather than calling the } \\
\text { designated family member for information. }\end{array}$ & $\begin{array}{llllll}0 & 1 & 2 & 3 & 4 & 5 \\
\bigcirc & \bigcirc & \bigcirc & \bigcirc & \bigcirc & \bigcirc\end{array}$ & $\begin{array}{llllll}0 & 1 & 2 & 3 & 4 & 5 \\
\square & \bullet & \square & \square\end{array}$ \\
\hline 17. & $\begin{array}{l}\text { Lack of nursing education and training regarding family } \\
\text { grieving and quality end-of-life care. }\end{array}$ & $\begin{array}{llllll}0 & 1 & 2 & 3 & 4 & 5 \\
\bigcirc & \bigcirc & \bigcirc & \bigcirc & \bigcirc & \bigcirc\end{array}$ & 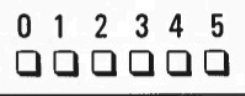 \\
\hline 18. & $\begin{array}{l}\text { Physicians who won't allow the patient to die from the } \\
\text { disease process. }\end{array}$ & $\begin{array}{llllll}0 & 1 & 2 & 3 & 4 & 5 \\
\bigcirc & \bigcirc & \bigcirc & \bigcirc & \bigcirc & \bigcirc\end{array}$ & $\begin{array}{llllll}0 & 1 & 2 & 3 & 4 & 5 \\
\square & \square & \square & \square\end{array}$ \\
\hline 19. & $\begin{array}{l}\text { Too many family members being allowed in the room during } \\
\text { resuscitation. }\end{array}$ & $\begin{array}{llllll}0 & 1 & 2 & 3 & 4 & 5 \\
\bigcirc & \bigcirc & \bigcirc & \bigcirc & \bigcirc & \bigcirc\end{array}$ & 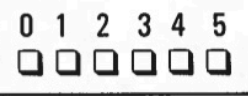 \\
\hline 20. & $\begin{array}{l}\text { Being called away from the patient and their family because } \\
\text { of the need to help with a new admit or to help another nurse } \\
\text { care for his/her patients. }\end{array}$ & $\begin{array}{llllll}0 & 1 & 2 & 3 & 4 & 5 \\
\bigcirc & \bigcirc & \bigcirc & \bigcirc & \bigcirc & \bigcirc\end{array}$ & $\begin{array}{l}0122345 \\
\square \square \square \square\end{array}$ \\
\hline 21. & $\begin{array}{l}\text { The ED nurse having too high a work load to allow for } \\
\text { adequate time to care for dying patients and their families. }\end{array}$ & $\begin{array}{llllll}0 & 1 & 2 & 3 & 4 & 5 \\
\bigcirc & \bigcirc & \bigcirc & \bigcirc & \bigcirc & \bigcirc\end{array}$ & $\begin{array}{llllll}0 & 1 & 2 & 3 & 4 & 5 \\
\square & \square & \square & \square & \square\end{array}$ \\
\hline 22. & $\begin{array}{l}\text { Family members not understanding what "life-saving } \\
\text { measures" really mean, i.e., that multiple needle sticks cause } \\
\text { pain and bruising, that an ET tube won't allow the patient to } \\
\text { talk, or that ribs may be broken during chest compressions. }\end{array}$ & $\begin{array}{llllll}0 & 1 & 2 & 3 & 4 & 5 \\
\bigcirc & \bigcirc & \bigcirc & \bigcirc & \bigcirc & \bigcirc\end{array}$ & 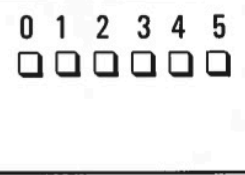 \\
\hline 23. & $\begin{array}{l}\text { The nurse not knowing the patient's wishes about continuing } \\
\text { treatments and tests because of the inability to communicate } \\
\text { due to a depressed neurological status or due to } \\
\text { pharmacologic sedation. }\end{array}$ & $\begin{array}{llllll}0 & 1 & 2 & 3 & 4 & 5 \\
\bigcirc & \bigcirc & \bigcirc & \bigcirc & \bigcirc & \bigcirc\end{array}$ & $\begin{array}{llllll}0 & 1 & 2 & 3 & 4 & 5 \\
\square & \square & \square & \square\end{array}$ \\
\hline 24. & The nurse having to deal with angry family members. & $\begin{array}{llllll}0 & 1 & 2 & 3 & 4 & 5 \\
\bigcirc & \bigcirc & \bigcirc & \bigcirc & \bigcirc & \bigcirc\end{array}$ & $\begin{array}{lllll}0 & 1 & 2 & 3 & 4 \\
\square & \square & \square & \square\end{array}$ \\
\hline
\end{tabular}

(C) Beckstrand 2011 Page -2- 
The following items pertain to your perceptions of possible obstacles to providing end-of-life care to dying patients and their families. As you read each item, please mark the circle that most closely characterizes how large an obstacle you have found each item to be then mark the box for how frequently you have experienced the obstacle as you have cared for dying patients.

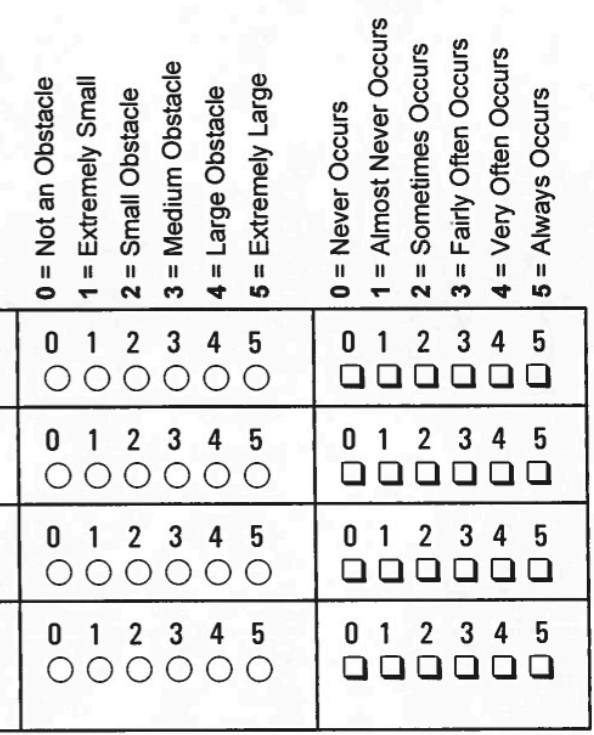

29. Please describe any missing obstacles in detail. Indicate how large each obstacle is and how frequently it occurs.

a.

b.

c.

\begin{tabular}{|c|c|c|c|}
\hline 25. & $\begin{array}{l}\text { The family, for whatever reason, is not with the patient when } \\
\text { he or she is dying. }\end{array}$ & $\begin{array}{llllll}0 & 1 & 2 & 3 & 4 & 5 \\
\bigcirc & \bigcirc & \bigcirc & \bigcirc & \bigcirc & \bigcirc\end{array}$ & $\begin{array}{llllll}0 & 1 & 2 & 3 & 4 & 5 \\
\square & \square & \square & \square & \square & \square\end{array}$ \\
\hline 26. & $\begin{array}{l}\text { Physicians who avoid having conversations with family } \\
\text { members. }\end{array}$ & $\begin{array}{llllll}0 & 1 & 2 & 3 & 4 & 5 \\
\bigcirc & \bigcirc & \bigcirc & \bigcirc & \bigcirc & \bigcirc\end{array}$ & $\begin{array}{llllll}0 & 1 & 2 & 3 & 4 & 5 \\
\square & \square & \square & \square & \square\end{array}$ \\
\hline 27. & $\begin{array}{l}\text { Multiple physicians involved with one patient who differ in } \\
\text { opinion about the direction care should go. }\end{array}$ & $\begin{array}{llllll}0 & 1 & 2 & 3 & 4 & 5 \\
\bigcirc & \bigcirc & \bigcirc & \bigcirc & \bigcirc & \bigcirc\end{array}$ & $\begin{array}{llllll}0 & 1 & 2 & 3 & 4 & 5 \\
\square & \square & \square & \square\end{array}$ \\
\hline 28. & $\begin{array}{l}\text { Physicians who order unnecessary tests or procedures for } \\
\text { dying patients just so they can say that every possibility was } \\
\text { considered. }\end{array}$ & $\begin{array}{llllll}0 & 1 & 2 & 3 & 4 & 5 \\
\bigcirc & \bigcirc & \bigcirc & \bigcirc & \bigcirc & \bigcirc\end{array}$ & $\begin{array}{llllll}0 & 1 & 2 & 3 & 4 & 5 \\
\square & \square & \square & \square & \square\end{array}$ \\
\hline
\end{tabular}

The following items pertain to your perceptions of possible helps to providing end-of-life care to dying patients and their families. As you read each item, please mark the circle that most closely characterizes how large a help you have found each item to be then mark the box for how frequently you have experienced the helpful behavior as you have cared for dying patients.
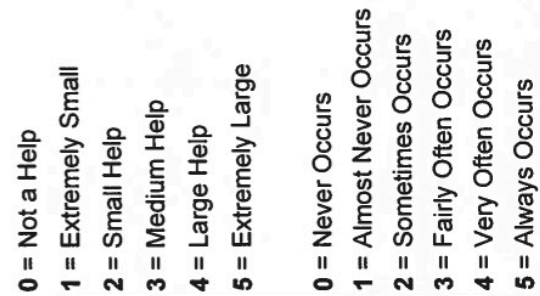

\begin{tabular}{|c|c|c|c|}
\hline 30. & $\begin{array}{l}\text { Having one family member be the designated contact person } \\
\text { for all other family members regarding patient information. }\end{array}$ & $\begin{array}{llllll}0 & 1 & 2 & 3 & 4 & 5 \\
\bigcirc & \bigcirc & \bigcirc & \bigcirc & \bigcirc & \bigcirc\end{array}$ & $\begin{array}{llllll}0 & 1 & 2 & 3 & 4 & 5 \\
\square & \square & \square & \square & \square & \square\end{array}$ \\
\hline 31. & $\begin{array}{l}\text { Having enough time to prepare the family for the expected } \\
\text { death of the patient. }\end{array}$ & $\begin{array}{llllll}0 & 1 & 2 & 3 & 4 & 5 \\
\bigcirc & \bigcirc & \bigcirc & \bigcirc & \bigcirc & \bigcirc\end{array}$ & $\begin{array}{llllll}0 & 1 & 2 & 3 & 4 & 5 \\
\square & \square & \square & \square & \square\end{array}$ \\
\hline 32. & $\begin{array}{l}\text { An emergency department designed so that the family has a } \\
\text { place to go to grieve in private. }\end{array}$ & $\stackrel{0}{\bigcirc} \stackrel{1}{\bigcirc} \stackrel{2}{\bigcirc} \stackrel{3}{\bigcirc} \stackrel{4}{\bigcirc} \stackrel{5}{\bigcirc}$ & $\begin{array}{llllll}0 & 1 & 2 & 3 & 4 & 5 \\
\square & \square & \square & \square & \square & \square\end{array}$ \\
\hline 33. & $\begin{array}{l}\text { Having the physicians involved in the patient's care agree } \\
\text { about the direction care should go. }\end{array}$ & $\begin{array}{llllll}0 & 1 & 2 & 3 & 4 & 5 \\
\bigcirc & \bigcirc & \bigcirc & \bigcirc & \bigcirc & \bigcirc\end{array}$ & $\begin{array}{llllll}0 & 1 & 2 & 3 & 4 & 5 \\
\square & \square & \square & \square\end{array}$ \\
\hline 34. & $\begin{array}{l}\text { The nurse drawing on his/her own previous experience with } \\
\text { the critical illness or death of a family member. }\end{array}$ & $\stackrel{0}{\bigcirc} \stackrel{1}{\bigcirc} \bigcirc \stackrel{3}{\bigcirc} \bigcirc \stackrel{4}{\bigcirc} \bigcirc$ & $\stackrel{0}{\bigcirc} \bigcirc \stackrel{2}{\bigcirc} \bigcirc$ \\
\hline
\end{tabular}

C Beckstrand 2011 Page -3- 


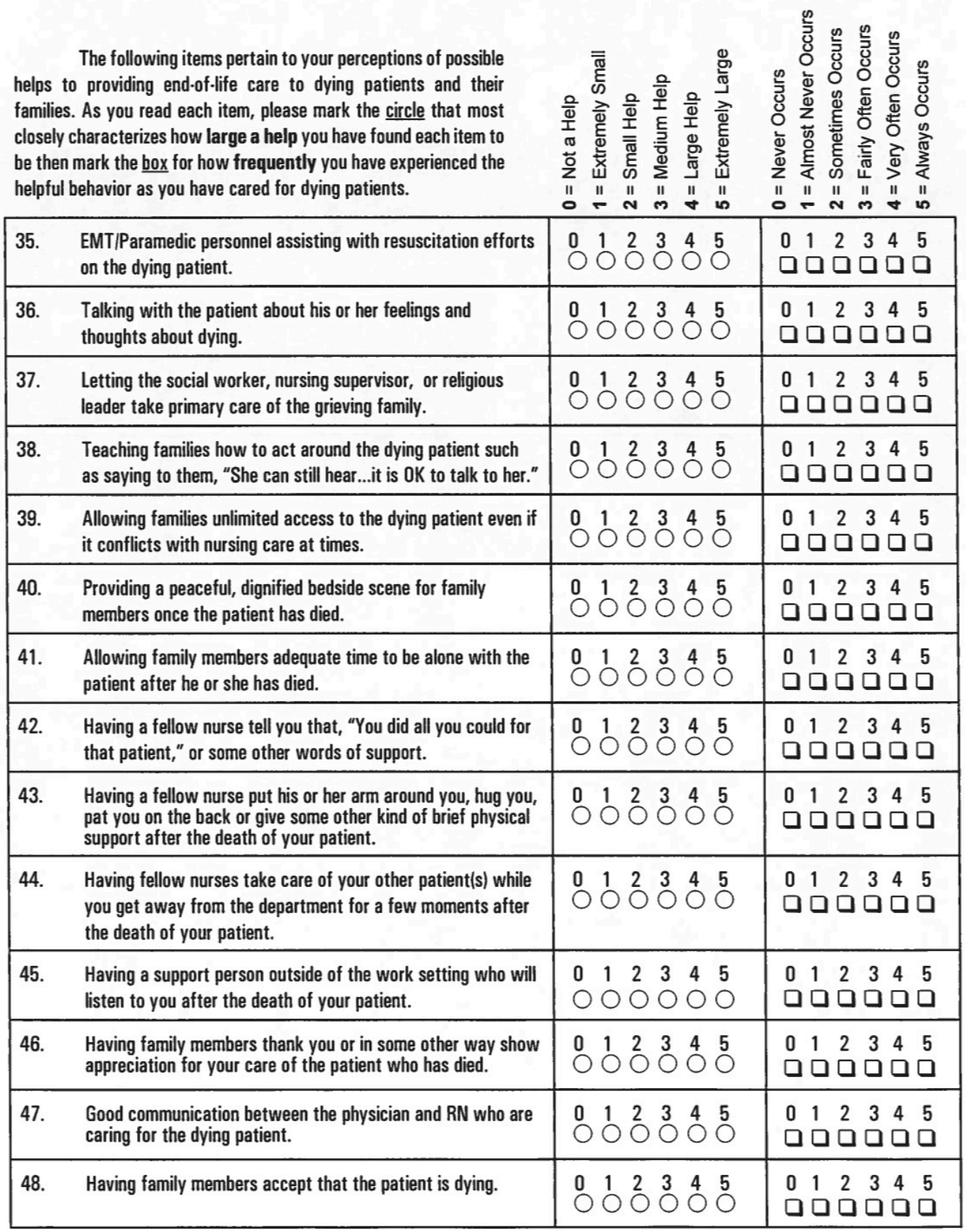




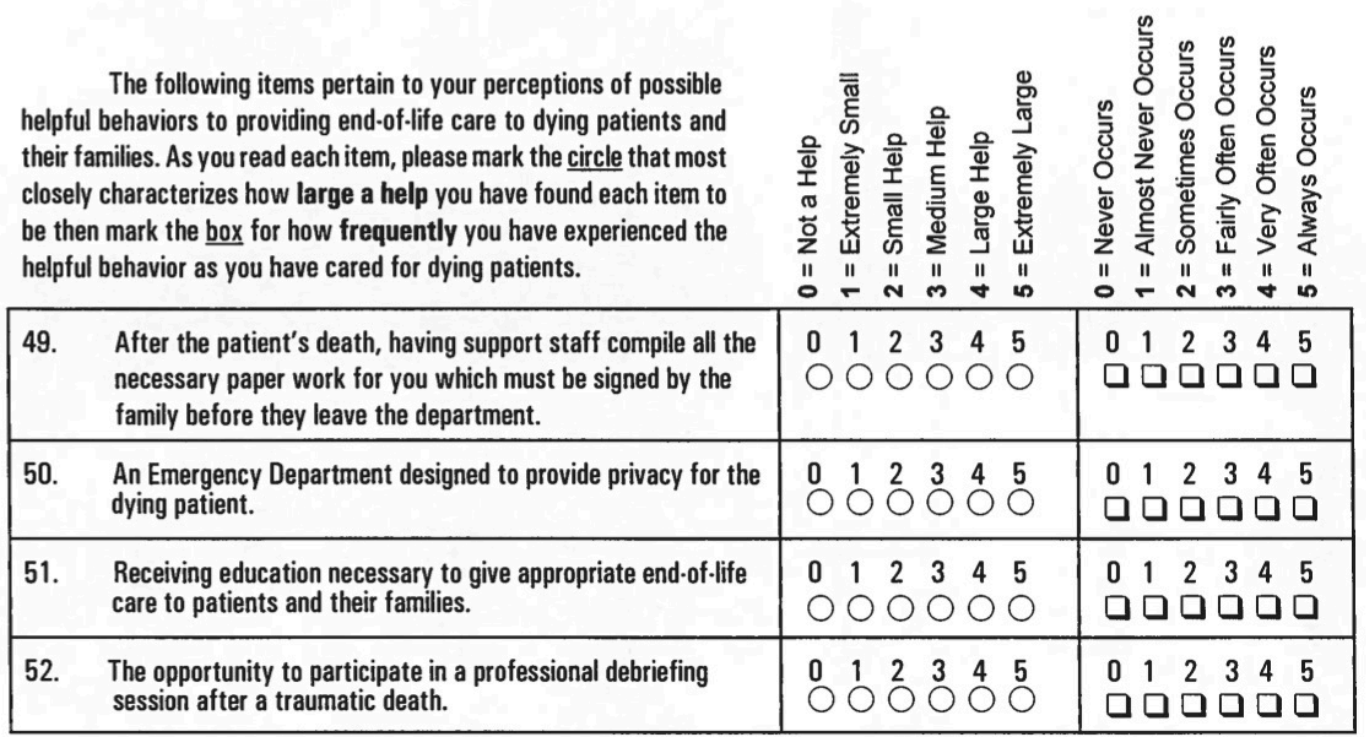

53. Please describe any missing helpful behaviors in detail. Indicate how large the help is and how frequently it occurs.

a.

b.

54. If you had the ability to change just one aspect of the end-of-life care given to dying ED patients, what would it be?

Now please tell a little about yourself by filling in the appropriate boxes below.

55. How many years experience do you have as an RN? $\square \square$

56. How many years of ER experience do you have?

57. What is your gender? $\square$ Male $\square$ Female

58. What year were your born? 19 $\square \square$

59. What is your highest completed level of education?
$\square$ Diploma in Nursing
$\square$ Bachelors degree, Nursing
$\square$ Masters degree, Other
$\square$ Associate degree, Nursing
$\square$ Bachelors degree, Other
$\square$ Doctoral degree
$\square$ Associate degree, Other
$\square$ Masters degree, Nursing
$\square$ Other

60. Over your nursing career, how many ED patients have you, yourself given immediate end-of-life care to?
$\square$ Less than 5
$\square$ Between 11 and 20
$\square$ Between 21 and 30
$\square$ More than 30
$\square$ Between 5 and 10

Beckstrand 2011 Page -5- 
61. In which type of ED are you primarily employed?

$\square$ Adult and Pediatric ED
$\square$ Other (Please specify)

62. In which type of facility are you primarily employed?
$\square$ Community Hospital, Non-profit
$\square$ Federal Hospital
$\square$ State Hospital
$\square$ Military Hospital
$\square$ Community Hospital, Profit
$\square$ County Hospital
$\square$ Other
$\square$ University Medical Center

63. The position you hold at the facility is?
$\square$ Direct care/Bedside/Staff Nurse
$\square$ Clinical Nurse Specialist
$\square$ Nurse Manager

$\square$ Charge Nurse/Staff Nurse

$\square$ Other (Please specify)

64. What is the number of beds in your unit?

65. How many hours per week do you usually work giving bedside care as an RN?

66. Have you ever been certified as a Certified Emergency Nurse (CEN)?
$\square$ No (Please skip to question \#69).
$\square$ Yes

67. Are you currently a CEN? $\square$ No $\square$ Yes

68. How many years have you held (or did you hold) the CEN certification? $\square \square$ years.

69. Do you currently have any other nursing certifications? If so, please list them now.

70. Do you have any comments about this study?

THANK YOU FOR YOUR PARTICIPATION IN THIS STUDY.

PLEASE RETURN THE QUESTIONNAIRE TODAY

IN THE ENCLOSED, STAMPED ENVELOPE

OR MAIL TO:

Renea Beckstrand

P.0. Box 25432, SWKT, Provo, UT 84602

Questions? $801422-3873$ or renea@byu.edu 
APPENDIX D: MODIFIED ELNEC TEST 
ELNEC Test Questions (with answers)

1. The nurse is having a discussion about barriers to quality end-of-life care with a coworker. Which comment by the co-worker indicates misunderstanding and the need for more information?

a. "A significant obstacle is health care professionals' lack of education about end-of-life care."

b. "One reason people don't seek palliative care is that they are reluctant to give up hope."

c. "The failure of health care professions to acknowledge the limits of traditional medicine is a major barrier."

d. "It's essential to know someone has six months or less to live for endof-life care to be started."

2. "Which approach by the nurse is most appropriate in caring for a dying patient?

a. Assist the patient and family to make choices regarding the final stage of life.

b. Explore choices that will avoid suffering for the patient and family.

c. Make decisions about physical care for the family to reduce their stress.

d. Advocate for the family to complete an advance directive for the patient.

3. When caring for patients at the end of life, the nurse can anticipate that these patients will have which two most common fears associated with death?

a. death itself and not finishing tasks

b. pain and being a burden to family

c. altered body image and not knowing what to expect

d. losing control and use of life-sustaining technology

4. Mr. F has advanced prostate cancer with bone metastasis. He is unresponsive, and is being cared for at home by his daughter. The home health nurse is teaching the daughter about assessing her father's pain. Which statement by the daughter indicates understanding of her father's pain status?

a. "If he is not moaning, he's probably not experiencing pain."

b. "I'll have to guess when he is in pain since he can't tell me."

c. "Now that he's unable to communicate, we can stop his pain medication."

d. "Since he was in pain when he was conscious, I assume he's still in pain."

5. The nurse is conducting a pain assessment for a female client with liver cancer. The client is complaining of right shoulder pain that is rated as a 9 on a 0 to 10 pain scale. Which action should the nurse take first?

a. Assess the patient's use of the prescribed pain medication.

b. Offer her a back massage to help her relax and decrease the pain. 
c. Place hot packs to the right shoulder to reduce localized pain.

d. Perform an assessment of her pulse and respiratory rate.

6. The nurse is admitting a client with metastatic breast cancer. The client has bleeding gums and guaiac positive stools. The client has an elevated temperature and a respiratory rate of 10 per minute. The client is complaining of aching and throbbing pain in the right femur. Which order should the nurse question?

a. Administer morphine sulfate $60 \mathrm{mg}$ PO every 4 hours for 24 hours.

b. Institute bleeding precautions.

c. Apply a transdermal fentanyl (Duragesic) patch $25 \mathrm{mcg} /$ per hour every 72 hours.

\section{d. Give ibuprofen (Motrin) $400 \mathrm{mg}$ every 4 hours for an elevated temperature.}

7. The nurse has attended a staff development conference on end-of-life pain management for clients who are substance abusers. Which statement by the nurse indicates a correct understanding of pain management for these clients with a history of substance abuse?

a. "They should not be given opioids for pain because of the high addiction risk."

b. "They will need smaller doses of analgesia to prevent cumulative overdose."

c. "They may require higher does of opioids to relieve their pain."

d. "They need to withdraw from the substance prior to receiving analgesia."

8. The nurse's 68-year-old patient is in the last hours of life after a lengthy illness. The patient has been receiving opioids for pain management. In assessing the patient as death approaches, the nurse knows that the opioid dose may need to be:

a. increased or decreased to maintain pain control

b. given only if requested by the patient

c. monitored as neuropathic pain increases as death approaches

d. discontinued due to diminished consciousness and altered mental state

9. The nurse is caring for Ms. P, a 55-year-old woman with cancer. She received pain medication less than two hours ago after which she expressed significant relief. A colleague now reports that Mrs. P is complaining of pain. The colleague says "She can't be hurting as much as she says she is." What is the nurse's most appropriate response?
a. "Pain is whatever she says it is. Let's assess her further."
b. "We need to explore the cultural meaning pain has for her."
c. "I will tell her gently that she must wait four hours between doses." 
d. "I'll wait to give the next dose and re-assess her a little early, in an hour."

10. The nurse is caring for a client who is in advanced stages of AIDS. The client is reporting fatigue. Which assessment finding is commonly associated with the symptom of fatigue?
a. anorexia /cachexia
b. reduced serum calcium
c. hyperthyroidism
d. increased hemoglobin/hematocrit

11. In assessing patients with dyspnea at the end of life, which statement is NOT true? Dyspnea:

a. occurs in the majority of advanced cancer patients

b. may be relieved by a cool fan blowing on the patient

c. responds well to oxygen even in non-hypoxemic patients

d. is assessed primarily by the patient's description

12. The nurse is caring for a man with advanced lung cancer who has an ongoing cough. The nurse correctly explains to the patient that his cough:

a. is a rare, but extremely annoying symptom associated with his disease

b. might be why he has experienced fatigue and vomiting recently

c. will not be as problematic if he lays flat and on his back in bed

d. may be diminished if he avoids coffee and other caffeinated beverages

13. In palliative care, the nurse cares for people of many cultures. When conversing with persons of another culture, the nurse should:

a. Use the patient's first name to establish warm rapport.

b. Determine who makes decisions for the patient and family.

c. Speak primarily to the translator rather than the patient or family.

d. Act as if the patient is fully informed of the diagnosis and prognosis.

14. The nurse is being oriented to palliative care. Which factor should the nurse identify as a requirement crucial to quality end-of-life care?

a. maintaining cost-effective analgesic regimens

b. restricting care to symptom management algorithms

c. communicating effectively with clients and families

d. employing volunteers to ensure clients are not alone

15. In preparing to discuss bad news with a patient, the palliative care nurse should:

a. Speak from the heart, without rehearsal to convey sincerity.

b. Determine what the patient and family already know.

c. Presume that patients want and need to be told the truth.

d. Be prepared to give advice about future treatment options. 
16. The nurse is caring for a man with advanced prostate cancer. He has been told that his therapy is not working. He asks the nurse, "Why is this happening to me?" What is the nurse's most appropriate response?
a. "I don't know. I wish I had an answer for you, but I don't."
b. "Perhaps you're being tested and this will make you a stronger person."
c. "I'll ask the doctor to more fully explain the disease process."
d. "If I were you, I'd explore additional therapies and treatment options."

17. The nurse is facilitating a staff discussion about myths and realities of communication in palliative care. Which is a correct statement about communication?
a. "We can never give someone too much information."
b. "We communicate only when we choose to communicate."
c. "The majority of messages we send are non-verbal."
d. "Communication is primarily words and their meanings."

18. Clients and families facing life-threatening illness expect that communication between themselves and a health care professional will include all of the following EXCEPT:
a. The professional will be honest/truthful in all communications.
b. The professional will discuss the client's care with the health care team.
c. The professional will decide what client issues need to be addressed first.
d. The professional will be available to listen to a client's concerns.

19. An 85-year-old client with end-stage heart disease arrives unconscious at the emergency department after sustaining her third myocardial infarction. The physician has told the daughter that without resuscitation, her mother could die today. The nurse finds the daughter crying by the client's bedside. Which intervention by the nurse is most appropriate in communicating with this family member?
a. Ask the daughter if she would like to reconsider treatment.
b. Talk to the physician about moving the client to a unit with more privacy.
c. Remain present with the daughter, using silence to impart comfort.
d. Assure the daughter that she doesn't need to stay with her mother.

20. The nurse is talking with the wife of a client who died recently. Which statement by the nurse is most helpful?
a. "I know exactly how you are feeling."
b. "It must be hard to accept that this has happened."
c. "His suffering is over. He's in a better place now."
d. "I'm here for you. Call me if you need anything." 
21. The nurse is caring for a patient who is very close to death. Of the following assessment findings, which is the most reliable sign of death?
a. Cheyne-Stokes respirations
b. mottling of extremities
c. absence of urine output
d. fixed, dilated pupils

22. The nurse is caring for an 85 year old man who is dying. He has been comatose for several days. His respirations are now shallow and rattling. His adult children at the bedside state, "We don't want our father to suffocate." Which action should the nurse take?
a. Use a suction machine to suction secretions from the mouth and the throat.
b. Sit the patient up and percuss the back to facilitate loosening of congestion.
c. Reassure the family that the rattling is normal and is not causing suffering.

d. Request an order for humidified oxygen to decrease the client's air hunger.

23. The nurse is caring for a man who is imminently dying. During morning care, the man asks the nurse if he is dying. An example of the best response for the nurse to give is:
a. "Yes. I suppose you've known this all along. I promise I'll be right with you all the way."
b. "Not today. Why don't we look at some of the things you would like to accomplish now?"
c. "Yes. Tell me about any concerns, fears, or questions you have about what will happen."
d. "Why do you ask that? You look like you feel so much better today than you did yesterday!"

24. The nurse is caring for a patient who has just died. In caring for the body after death, the goal of care is to:
a. Make sure the body is sent to the morgue within an hour after death.
b. Have the family members participate in the bathing and dressing the deceased.
c. Notify all family members and team members regarding the patient's death.
d. Provide a clean, peaceful impression of the deceased for the family.

25. The nurse is caring for a patient who has just died. The family is weeping at the bedside. In assisting the family to understand what will occur next, the nurse should: 
a. Explain how the body will be cared for immediately following the death.

b. Request that the family leave the room in order for the body to be washed.

c. Give information about the need to remove the body promptly for embalming.

d. Ask if they would like to have all the tubes, catheters and IV lines removed. 